Georgia State University

ScholarWorks @ Georgia State University

$10-1-2018$

\title{
Some Like it Hot: Assessing Longer-term Labor Market Benefits from a High-Pressure Economy
}

Julie L. Hotchkiss

Federal Reserve Bank of Atlanta, julie.I.hotchkiss@atl.frb.org

Robert E. Moore

Georgia State University, rmoore@gsu.edu

Follow this and additional works at: https://scholarworks.gsu.edu/uwrg_workingpapers

\section{Recommended Citation}

Hotchkiss, Julie L. and Moore, Robert E., "Some Like it Hot: Assessing Longer-term Labor Market Benefits from a High-Pressure Economy" (2018). UWRG Working Papers. 125.

https://scholarworks.gsu.edu/uwrg_workingpapers/125

This Article is brought to you for free and open access by the Usery Workplace Research Group at ScholarWorks @ Georgia State University. It has been accepted for inclusion in UWRG Working Papers by an authorized administrator of ScholarWorks @ Georgia State University. For more information, please contact scholarworks@gsu.edu. 


\section{W. J. Usery Workplace Research Group Paper Series}

Working Paper 2018-10-1

October 2018

\section{Some Like It Hot: Assessing Longer-term Labor Market Benefits from a High- Pressure Economy}

Julie L. Hotchkiss

Federal Reserve Bank of Atlanta

Georgia State University

\section{Robert E. Moore}

Georgia State University

\section{ANDREW YOUNG SCHOOL}




\title{
Some Like it Hot: Assessing Longer-term Labor Market Benefits from a High-Pressure Economy
}

\author{
Julie L. Hotchkiss* \\ Federal Reserve Bank of Atlanta \\ and Georgia State University \\ Research Department \\ 1000 Peachtree St. NE \\ Atlanta, GA 30309 \\ Julie.L.Hotchkiss@atl.frb.org \\ 404-498-8198
}

\author{
Robert E. Moore \\ Georgia State University \\ Department of Economics \\ P.O. Box 3992 \\ Atlanta, GA 30302-3992 \\ rmoore@gsu.edu \\ 404-413-0056
}

October 17, 2018

\begin{abstract}
This paper explores evidence for positive hysteresis in the labor market. Using data from the National Longitudinal Surveys of Youth, we find that negative labor market outcomes during high unemployment periods are mitigated by exposure to a high-pressure economy during the preceding expansion. Breaking total exposure into intensity and duration suggests that these two dimensions have differing impacts. However, the benefits of exposure are not enough to overcome the greater negative impact of high unemployment periods on labor market outcomes of disadvantaged groups, making extension of high-pressure economic environments ineffective in reducing labor market gaps.
\end{abstract}

JEL Classifications:

E60 - Macroeconomic Policy - general

E24 - Employment; Unemployment; Wages; Intergenerational Income Distribution; Aggregate Human Capital; Aggregate Labor Productivity

J64 - Unemployment: Models, Duration, Incidence, and Job Search

J31 - Wage Level and Structure; Wage Differentials

Key Words: hysteresis, labor force participation, labor market gaps, unemployment, wage gaps

*Corresponding author. This research was conducted with restricted access to Bureau of Labor Statistic (BLS) data. The views expressed here do not necessarily reflect those of the Federal Reserve Bank of Atlanta, the Federal Reserve System, or the BLS. Research assistance from Kalee Burns, Ellie Terry, Taylor Kelley, and Deepmala Pokhriyal is much appreciated, and thanks are extended to Lisa Cook, Mary Daly, Bruce Fallick, Patrick Higgins, Carl Hudson, Philip Jefferson, Pia Orrenius, Melinda Pitts, William Roberds, John Robertson, William Spriggs, Sam Schulhofer-Wohl, and the participants of the California State University-Long Beach Economics Department Seminar Series for helpful comments and suggestions. 


\section{Some Like it Hot: Assessing Longer-term Labor Market Benefits from a High-Pressure Economy}

\section{Introduction and Background}

The purpose of this paper is to investigate whether the expected positive effects of exposure to a "high-pressure" economy also impacts labor market outcomes during the following high-unemployment period and the subsequent period of low-unemployment. In other words, can we find evidence of positive hysteresis from high-pressure exposure? We also investigate whether intensity or duration of high-pressure episodes have differential impacts. Using the 1979 and 1997 National Longitudinal Surveys of Youth (NLSY), the analysis will be at the individual worker level and allow individuals to potentially be observed across multiple business cycles, to be able to assign residence during high-pressure exposure, and to control for individual fixed effects. Labor market outcomes examined here are unemployment, labor force participation, hourly wages, and weekly hours of work. Since the declaration of a national recession may not necessarily coincide with an individual's state's economic environment, the analysis considers outcomes during state-specific "high-unemployment" periods, which are defined below. The results are consistent with those obtained when periods of national recession are used instead of state-specific high-unemployment periods.

A high-pressure economy is generally agreed to be one in which the unemployment rate is below the natural, or sustainable or long-term, unemployment rate -- that level of unemployment that can be maintained without putting too much pressure on inflation (Condon and Torres 2016). There is also general agreement that a high-pressure economy has potential risks, including financial instability, vulnerability to adverse shocks that could lead to recession, and could generally be a signal that an economy's long-run growth prospects are dim (Fischer 2016). In other words, if the demand for resources (including labor) expands beyond the 
economy's capacity to supply them, the risk of undesirable inflation, financial imbalances, and other negative developments may grow. ${ }^{1}$

High-pressure (HP) economies, however, have also been found to have significant contemporaneous benefits to workers. Okun (1973) describe the environment as one in which disadvantaged workers experience upward mobility as increased demand makes employers dig deeper into their available labor pool (also see Krause and Lubik 2006). Rose et al. (1988) explain that the ability of workers to easily switch jobs during a high-pressure episode allows them to find better job matches in both the pecuniary and non-pecuniary dimensions. And, as might seem obvious, greater demand bids up the price of labor so workers experience greater wage growth during high-pressure periods (Holzer et al. 2006). The antithesis of this, of course, is that we would see lower wages, at least entry-level wages, during recessions (Carneiro et al. 2012; Martins et al. 2012). Evidence that high-pressure economies improve the relative unskilled-to-skilled unemployment experience is also found in Jefferson (2005). As workers' wages are bid up and as employers have to dig deeper into the labor pool to meet demand during high-pressure economies, we might expect that these gains would be expressed as better outcomes in the future.

There is evidence of significant disparities in labor market outcomes across the business cycle. The identification of "large unemployment disparities" as a "social issue" has a long history, dating back at least to Perry (1970) identification of structural factors playing a role in the relationship between what level of unemployment can be attained at a given level of inflation, and Hall (1970) considers of whether the notion of "normal" unemployment differs by

\footnotetext{
${ }^{1}$ The natural tension between low unemployment and low inflation is reflected in the wellknown Phillips Curve (Fisher 1926; Phillips 1958), which, of course, is not without its critics (e.g., Atkeson and Ohanian 2001; Gordon 2011; King and Watson 1994; Lucas and Sargent 1978).
} 
race and gender. A more recent analysis is offered by Cajner et al. (2017) who find that not only are blacks (and Hispanics) hit harder by recessions, their experience is more volatile across the business cycle (also see Zavodny and Zha 2000); and Jefferson (2008), who finds a similar result among the less educated). In other words, strong recoveries can go a long way to diminishing the economic disparities of disadvantaged groups (also see Couch and Fairlie 2010; Engemann and Wall 2010). To the extent that policy makers desire to reduce labor market outcome gaps between advantaged and disadvantage groups, then, they may want to do what they can to sustain high-pressure economic environments. Whether these gap shrinkages persist is another question.

The evidence as to whether high-pressure economies have a lasting, longer-term impact on labor market outcomes of workers (i.e., positive hysteresis) is thin and varied. In the aggregate, Fleischman and Gallin (2001) find that positive aggregate economic shocks do not translate into persistently higher employment rates, however, there is more of a positive impact on younger workers compared with older workers. Kahn (2010) provides evidence of negative hysteresis in wages of white men who graduate from college during a recession; they experience lower wages for decades after graduating. The long-term cost of recessions to new graduates is also documented by Cockx and Ghirelli (2016), Fernández-Kranz and Rodríguez-Planas (2018), Kondo (2015), Liu et al. (2016), Oreopoulos et al. (2012), and von Wachter and Bender (2006). Other evidence suggests that the lasting effects of recessions also affect health (Maclean 2013) and self-esteem (Maclean and Hill 2015). Yagan (2017) also attributes most of the employment decline between 2007 and 2015 to local unemployment shocks during the great recession. Of course, these studies follow on a long literature of the scaring effects of unemployment, more generally (for example see Ellwood 1982; Schmillen and Umkehrer 2017). 
One part of the analysis presented here has potential implications for the debate about whether implicit contracts or the spot market is the best mechanism describing wage dynamics (Beaudry and DiNardo 1991; Devereux and Hart 2007). If wages are solely determined by the spot market (current labor market conditions), then exposure to a high-pressure economy should not affect wage outcomes during the following high-unemployment period. On the other hand, Beaudry and DiNardo show that wages will be correlated with economic conditions if wages are determined by contracts; wages will be most strongly correlated with economic conditions at the time of initial hiring if workers are not mobile, but with the strongest economic condition since being hired if workers are very mobile.

Results in this paper suggest that exposure to a high-pressure economy during an expansion reduces the unemployment experience, increases labor market attachment, and moderates wage and hours losses during the following period of high unemployment. Breaking total high-pressure exposure into its average intensity and duration, suggests that these two factors have differing impacts depending on the outcome.

Additionally, the effect of high-pressure exposure appears to reach into the next expansion to varying degrees. An important observation, however, is that while the moderating effects of high-pressure exposure are statistically significant, predicted outcomes only differ significantly from those with zero exposure when the level of exposure is relatively high. The finding of only modest and not particularly long-lasting positive impacts of a high-pressure economy on labor market outcomes is consistent with Fallick and Krolikowski (2018) who estimate only weak and short-lived hysteresis in employment rates among less-educated primeage males and with Chetty et al. (2018) who present evidence of much deeper roots for ongoing racial disparities, particularly among men. 


\section{Quantifying State-level High-pressure Time Periods}

As mentioned above, identifying a high-pressure economic environment amounts to comparing the actual unemployment rate to the long-term unemployment rate (LTUR). The estimate of the LTUR for the United States is provided by the Congressional Budget Office (CBO) based on a set of Philips curve equations, which describe an inverse relationship between the rate of unemployment and the rate of inflation (Arnold 2008; CBO 1994). ${ }^{2}$ Since the notion of state-specific inflationary pressures isn't realistic, the CBO does not construct a LTUR for each state separately. However, employment conditions can vary widely across states. Therefore, we construct state-specific LTURs based on the CBO's estimation of the national LTUR and a state's long-term employment condition relative to the national condition. While state and regional unemployment rates are expected to follow similar trends (Hotchkiss 1991), the levels experienced by workers can vary dramatically across states (Walden 2012).

Each state's LTUR is constructed by adjusting the CBO's national LTUR by the difference between the average state and national unemployment rates between 1976 and 2015 -a state-specific shift in the LTUR as reported by the CBO. We make use of monthly Current Population Survey (CPS) data between 1976 and 2015 to calculate each state's average annual unemployment rate. The CPS is administered each month by the U.S. Bureau of Labor Statistics to roughly 60,000 households. This is the nationally representative cross-sectional survey from

\footnotetext{
${ }^{2}$ We make use of the CBO's LTUR, rather than the "Natural" unemployment rate since the CBO did not make explicit adjustments to the natural rate for structural factors before the Great Recession. CBO's estimates of potential GDP are based on the underlying LTUR. See "Potential GDP and Underlying Inputs" on the CBO's web page for historical estimates for the underlying long-term national unemployment rate: https://www.cbo.gov/about/products/budget-economicdata\#6.
} 
which we get reports of the unemployment rate and the labor force participation rate, among other monthly labor market statistics.

As an example, Figure 1 illustrates high-pressure exposure for two very different states - North Dakota (state fips code 38) and Mississippi (state fips code 28). ${ }^{3}$ The orange dashed line reflects the national LTUR. Note that North Dakota's actual unemployment rate (the green line) is almost always below the national LTUR and Mississippi's actual unemployment rate is almost always above the national LTUR. The gray bars reflect years in which the U.S. economy was in a recession. Using annual averages, periods of high-unemployment are those when the state's unemployment rate falls above the state's LTUR (indicated by the solid black line).

[Figure 1 about here]

Adjusting for the consistently low unemployment experience of North Dakota and the consistently high unemployment experience of Mississippi produces much lower overall highpressure exposure for North Dakota residents, relative to those living in Mississippi, indicated by the red line which is plotted as equal to one during high-pressure periods (the red line). Total high-pressure exposure during an expansion is calculated as the discrete sum (i.e., area) of the difference between the state's long-term and annual average rates of unemployment. For example, the only high-pressure period experienced in North Dakota over this time period was in the late 1990s and it was not very intense, just equal to 0.05. Mississippi experienced six instances of high-pressure exposure. The three intermittent high-pressure periods in the mid2000s are averaged to obtain the total exposure of high-pressure during that expansion. For example, during that expansion, residents of Mississippi experienced a total high-pressure exposure of 0.55 . In the estimating sample, the median level of total high-pressure exposure is

${ }^{3}$ Similar graphs for all fifty states are included in an appendix, available upon request. 
1.7. Since each high-pressure period has both a level of intensity (how much the state's unemployment rate falls below its natural rate) and duration (how long the state's unemployment rate stays below its natural rate), the total exposure will also be decomposed into these two components for analysis.

\section{The National Longitudinal Surveys of Youth (1979 and 1997)}

The National Longitudinal Surveys of Youth (NLSY79 and NLSY97) are nationally represented annual surveys started in 1979 and 1997 of young people born between 1957 and 1965 (NLSY79) and young people born between 1980 and 1984 (NLSY97). ${ }^{4}$ The NLSY79 started with 12,686 respondents and NLSY97 started with 8,984. The annual NLSY79 surveys became biennial after 1994. Figure 2 illustrates the oldest and youngest ages we have from each survey in each year, along with recessionary bars. Since we restrict the analysis to those 18 years and above, we will have fewer observations from NLSY97 during the 2001 recession, but will have observations from both full samples during the 2008-2009 recession. The last year of data for the 1979 cohort is 2014 and for the 1997 cohort is 2013. In creating consistent demographic comparison groups across cohorts, only three racial groups are identified for the NLSY79 cohort, requiring all racial groups other than black, non-Hispanic and Hispanics to be grouped with white, non-Hispanics.

[Figure 2 about here]

The differences in average characteristics across cohorts and by age can be seen in the sample means of Table 1. Note that the cohorts overlap in only two of the age groups in the table. The rise in average educational attainment over time can be seen comparing cohorts within

\footnotetext{
${ }^{4}$ See https://www.bls.gov/nls/nlsy79.htm and https://www.bls.gov/nls/nlsy97.htm
} 
age group - the share with less than a high school degree is lower and the share with college or more is higher among the NSLY97 cohort.

[Table 1 about here]

We restrict the sample to include individuals 18 and older; the maximum age in the sample is 57 . The higher share of black and Hispanic observations than one might expect reflects the oversampling of these groups by the NLSY. The means are unweighted to more accurately reflect the characteristics of the sample used for the analyses. ${ }^{5}$ The next two sections illustrate sample averages for two of the labor market outcomes evaluated here -- share of time in the labor force spent unemployed and real hourly pay.

\subsection{Share of Time Spent Unemployed in High- and Low-Unemployment Periods}

Figure 3 illustrates the share of time in the labor force during the year that is spent unemployed, separately by high- and low-unemployment periods. ${ }^{6}$ The share of time spent unemployed is like a personal unemployment rate, designed to abstract from the labor supply decision. As expected, the share of time spent unemployed is higher, on average, during periods of high unemployment across all demographic groups. Figure 3 also shows that the higher share of time spent unemployed in both period types is higher for more disadvantaged groups (racial minorities, the young, and the less educated). In addition, on average, women appear to spend a greater share of their time in the labor force unemployed than men. The analysis below will also evaluate labor market attachment through the share of total time spent in the labor force.

[Figure 3 about here]

\footnotetext{
${ }^{5}$ For more information on oversampling and sampling weights in the NLSY see: https://www.nlsinfo.org/content/cohorts/nlsy97/using-and-understanding-the-data/sampleweights-design-effects/page/0/0/\#practical

6 High-unemployment periods are defined above. Low-unemployment periods are those during which the state's unemployment rate falls below the state's LTUR.
} 


\subsection{Real Hourly Pay in High- and Low-unemployment Periods}

The debate over whether real wages differ across the business cycle has a long history (for example, see Abraham and Haltiwanger 1995). If workers suffer losses in real wages, it might be possible that those losses are mitigated from exposure to a high-pressure economy prior to the recession. If a high-pressure economy allows workers to experience greater upward mobility (Krause and Lubik 2006; Okun 1973) or better job matches (Rose et al. 1988), those benefits might extend beyond the expansion into the next high-unemployment period. While evidence from the literature suggests a strong relationship between real wages and the business cycle (Otrok and Pourpourides 2017), others find that expansionary wage boosts do not persist once someone loses their job (Schmieder and von Wachter 2010).

Figure 4 illustrates the average real hourly pay (in 2014 dollars) across demographic groups during high- and low-unemployment periods. Perhaps unexpectedly, hourly pay, on average, is mostly higher during high-unemployment periods. The estimation sample requirement of being employed may be biasing the high-unemployment means upward. In other words, if the less productive are laid-off during high-unemployment periods (i.e., recessions), then those who are left will be the higher-paid workers. And, as will be seen below, once we control for individual characteristics, high-unemployment periods have a depressing effect on real hourly pay. We do see, however, that wages are lower overall among less advantaged groups, in both high- and low-unemployment periods. In addition to hourly pay, the analysis below will also consider weekly hours of work.

[Figure 4 about here] 


\section{Modeling the Impact of High-pressure Exposure on Labor Market Outcomes}

\section{$\underline{4.1 \text { Total Exposure }}$}

The overarching question posed in this paper is whether greater exposure to a highpressure environment during an expansion moderates the labor market experience during the following high-unemployment period. The share of time spent unemployed, the share of time spent in the labor force, real hourly pay, and weekly hours are the labor market outcomes analyzed. Since even longer term labor market outcomes are of particular interest for labor market gaps between advantaged and disadvantaged demographic groups (Antecol and Bedard 2004), we will also explore whether high-pressure exposure reaches beyond the following high unemployment period into the subsequent low-unemployment period.

Labor market outcome (LMoutcome ist $)$, of person $i$, in year, $t$, in state, $\mathrm{s}$, is expressed as a function of the person's individual demographics, whether the observation is during a highunemployment year $(H U)$, and the extent to which the person was previously exposed to a highpressure environment:

$$
\begin{aligned}
& \text { LMoutcome }_{\text {ist }}=\alpha+\sum_{k=2}^{4}\left\{A G E_{i}^{k}\left(\delta_{1 k}+\delta_{2 k} H U_{t}+\delta_{3 k} H U_{t} H P s u m_{s h}\right)\right\} \\
& +\sum_{k=2}^{3}\left\{R A C E_{i}^{k}\left(\beta_{1 k}+\beta_{2 k} H U_{t}+\beta_{3 k} H U_{t} H \text { Psum }_{s h}\right)\right\} \\
& +\sum_{k=2}^{4}\left\{E D U C_{i}^{k}\left(\varphi_{1 k}+\varphi_{2 k} H U_{t}+\varphi_{3 k} H U_{t} H P s u m_{s h}\right)\right\} \\
& +\operatorname{MALE}_{i}\left\{\theta_{1}+\theta_{2} H U_{t}+\theta_{3} H U_{t} H P \text { sum }_{s h}\right\}+H U_{t}\left\{\rho_{1}+\rho_{2} H P \text { sum }_{s h}\right\} \\
& +\tau_{t}+\sigma_{s}+\pi_{i}+\varepsilon_{i s t}
\end{aligned}
$$

Each demographic category (Age, Race, Education, and Male) enters on its own and is interacted with a high-unemployment dummy $\left(H U_{t}\right)$, plus a high-unemployment dummy modified by the total high-pressure exposure during the expansion prior to the high-unemployment period, $h$ 
$\left(\right.$ HPsum $\left._{\text {sth }}\right):^{7}$

$\operatorname{HPsum}_{s h}=\sum_{t=1}^{N}\left\{L T U R_{s}-U R_{t s h}\right\}$,

where $N$ is the equal to the number of years during high pressure period, $h$, that the long-term unemployment rate for state, $s$, exceeds the current unemployment rate in year $t$. For modeling purposes, we need well-defined periods that precede a high-unemployment period during which we assess a person's high-pressure exposure. We, therefore, identify high-pressure exposure only if it is present during an NBER determined expansionary period for the U.S. economy.

HPsum enters the regression as a modifier for the impact of high-unemployment periods. Note that the regression includes year $\left(\tau_{t}\right)$, state $\left(\sigma_{s}\right)$, and person $\left(\pi_{i}\right)$ fixed effects. Of course the race and sex indicators are not identified when the individual fixed effect is included as a regressor, but the impact of high-unemployment and the moderating effect of high-pressure intensity for all groups is. Estimation is performed via Ordinary Least Squares (OLS) and standard errors are clustered at the state level.

In order to have more confidence in the accuracy of time spent in the labor force, we restrict the sample to those who reported at least 44 weeks of total activity during the year (including employed, unemployed, and out of the labor force). We also restrict the analysis of hourly pay and weekly hours to those with non-zero wages and hours, respectively. Additionally, since the mechanism for high-pressure environments to modify recession experiences is expected to be the actual labor market experience during the preceding expansion, the sample is also restricted to those having non-zero employment at some point during the preceding expansion.

\footnotetext{
${ }^{7}$ An analysis using an indicator for national recessions, instead of state-specific highunemployment periods is discussed below.
} 
Given the regressors of interest, one could argue that it is unnecessary to control for individual fixed effects in this model. This question depends on whether it's reasonable to expect that an unobserved individual characteristic is correlated with how a high-pressure economy moderates a person's labor market experience during high-unemployment periods. For example, suppose industriousness is related to the intensity of high pressure a person experiences prior to a period of high unemployment, say, through migration decisions (i.e., more industrious people migrate to high-pressure states). We might also expect industriousness to impact a person's labor market experience during high-unemployment periods. Then, controlling for individual fixed effects would remove that characteristic's confounding influence from the estimated moderating influence of high-pressure exposure on the impact of high-unemployment periods on labor market outcomes. We will illustrate the implication of not controlling for individual fixed effects below.

\subsection{Intensity vs. Duration}

Periods of high-pressure exposure differ across two potentially important dimensions -intensity (how far does the actual unemployment rate get below the natural rate of unemployment?) and duration (how long does the high-pressure environment persist?). Equation (1) is modified and re-estimated to "decompose" the effect of high-pressure exposure into these components: 


$$
\begin{aligned}
\text { LMoutcome }_{i s t}=\alpha & +\sum_{k=2}^{4}\left\{A G E_{i}^{k}\left(\delta_{1 k}+\delta_{2 k} H U_{t}+\delta_{3 k} H U_{t} H P a v g_{s h}+\delta_{4 k} H U_{t} H P n_{s h}\right)\right\} \\
& +\sum_{k=2}^{3}\left\{R A C E_{i}^{k}\left(\beta_{1 k}+\beta_{2 k} H U_{t}+\beta_{3 k} H U_{t} H P a v g_{s h}+\beta_{4 k} H U_{t} H P n_{s h}\right)\right\} \\
& +\sum_{k=2}^{4}\left\{E D U C_{i}^{k}\left(\varphi_{1 k}+\varphi_{2 k} H U_{t}+\varphi_{3 k} H U_{t} H P a v g_{s h}+\varphi_{4 k} H U_{t} H P n_{s h}\right)\right\} \\
& +M A L E_{i}\left\{\theta_{1}+\theta_{2} H U_{t}+\theta_{3} H U_{t} H P a v g_{s h}+\theta_{4} H U_{t} H P n_{s h}\right\} \\
& +H U_{t}\left\{\rho_{1}+\rho_{2} H P a v g_{s h}+\rho_{3} H P n_{s h}\right\}+\tau_{t}+\sigma_{s}+\pi_{i}+\varepsilon_{i s t} .
\end{aligned}
$$

In equation (3), the measure of total high-pressure exposure $\left(H_{P s u m}\right)$ is replaced with it's two characteristics -- intensity $\left(\mathrm{HPavg}_{\mathrm{sh}}\right)$, or, the average percentage point difference between the state's long-term and actual unemployment rates during high-pressure period, $h$, and duration $\left(H P n_{s h}\right)$, the total number of years that the actual unemployment rate fell below the long-term unemployment rate during high-pressure period, $h .^{8}$

There may be reason to expect that either intensity or duration may differ in importance for moderating the effect of high-unemployment periods on different outcomes. For example, a more intense high-pressure period may mean the employer has to adjust quickly to large shifts in demand requiring additions to the production process on the extensive margin -- i.e., raising wages to quickly attract more workers. On the other hand, an employer may be able to respond to a period of high-pressure that is not as intense, but lasts longer, by making adjustments on the intensive margin -- i.e., increasing hours of existing workforce. The question, then, is whether these experiences extend into the next high-unemployment period.

\footnotetext{
${ }^{8}$ Technically, a linear decomposition would make use of logs. Since HPsum $=N * H P a v g$, therefore $\log ($ HPsum $)=\log (N)+\log ($ HPavg $)$. However, the presence of zeros for both HPavg and $N$, make the log specification problematic.
} 


\subsection{Impact of High-pressure Exposure into the Next Low-unemployment Period}

In order to assess the impact of high-pressure exposure on longer-term labor market outcomes, equation (1) is re-estimated for all outcomes during the next low-unemployment period -- the low-unemployment period following the expansion in which the high-pressure environment was experienced. These two time periods are separated by a period of highunemployment. So, instead of a high-unemployment indicator, there will be a lowunemployment indicator, plus the low-unemployment indicator modified by total high-pressure exposure during the previous expansion. In other words, does the impact of the high-pressure environment to which someone is exposed reach beyond the immediately following highunemployment period into the next low-unemployment period?

\section{Results}

\subsection{Impact of Total High-pressure Exposure}

Table 2 reports the estimated marginal effects of high-unemployment periods and the moderating influence of exposure to a high-pressure economy during the preceding expansion on the share of time spent unemployed, the share of the time spent in the labor force, log real hourly pay, and weekly hours of work. The marginal benefit of high-pressure exposure that are statistically significant at conventional levels are in bold.

[Table 2 about here]

Overall, on average across the full sample, during periods of high-unemployment, workers spend a greater share of their time unemployed (about 1.2 percentage points), less time in the labor market (but not statistically significant), face lower wages (about two percent), and work fewer hours per week (about 17 minutes). For the most part, disadvantaged workers (e.g., 
less education, non-white) are hit harder by high-unemployment periods. ${ }^{9}$ These results are generally consistent with much of the literature that finds that more disadvantaged groups face worse labor market outcomes during recessions (Cajner et al. 2017; Engemann and Wall 2010; Hoynes et al. 2012).

Additionally, across the full sample, greater exposure to a high-pressure environment during the previous expansion significantly moderates the impact of high-unemployment, except with respect to hours of work. The only demographic group whose hours during a highunemployment period are improved from high-pressure exposure are blacks. Also, when highpressure exposure benefits workers, less advantaged workers generally benefit more, especially blacks, the young, and those with less education. ${ }^{10}$ These results are consistent with those in the literature that suggest that particularly strong growth can help to narrow labor market disparities between advantaged and disadvantaged workers (Bradbury 2000; Couch and Fairlie 2010).

In spite of the fact that, for the most part, disadvantaged workers' labor market outcomes benefit more than the outcomes among advantage workers, from previous high-pressure exposure, the net effect of high-unemployment (impact of high-unemployment plus benefit of high-pressure exposure) is smaller for the advantaged groups (except older workers) for all outcomes. In other words, the larger benefit from high-pressure exposure experienced by less advantaged workers is not enough to offset the larger hit during a high-unemployment period. For example, the net impact of a high-unemployment period on real hourly pay among blacks, at

9 The exception is older workers and men who face greater wage and hours losses on average than younger workers and women, respectively.

${ }^{10}$ Again, an exception can be found for men, whose time spent in the labor force, hours (not significantly), and wages during high-unemployment periods benefit more from previous high pressure exposure than women's hours and wages. 
the median total high-pressure exposure of 1.7 , is $-0.0226 .{ }^{11}$ This is a larger average net wage loss than experienced by whites $(-0.0123)$. This result differs from that of Biddle and Hamermesh (2013) who find that the wage disadvantage between whites and blacks decreases with negative shocks. However, the result is consistent with Jefferson $(2005,2008)$ who finds that economic downturns are fundamentally worse events for disadvantaged workers (i.e., blacks and the less educated). Additional evidence is found for the other outcomes, as well. The net impact of a high-unemployment period for blacks (vs. whites) who experienced a median amount of high-pressure exposure is 1.8 (vs. 0.8) percent more time unemployed and about 24 (vs. zero) minutes fewer hours per week (the net impact on time spent in the labor force is not significantly different from zero for either whites or blacks). The comparison of net outcomes is mixed across age groups, but those with less education tend to have worse net unemployment, wages, and hours outcomes compared to those with more education. When statistically significant, the net outcome on labor force participation for someone with a median level of high-pressure exposure is generally positive.

\subsection{Statistically Significant Slopes vs. Statistically Significant Impact}

It is one thing to estimate a statistically significant marginal effect of high-pressure exposure on labor market outcomes, but quite another for the predicted impact to be meaningful at reasonable high-pressure values. Figure 5 shows that, for the full sample, on average, only time spent in the labor force is significantly impacted (relative to zero exposure) at high-pressure exposure at the 25th percentile. Someone has to be exposed to at least a median level of highpressure for their share of time spent unemployed to be reduced, relative to someone with zero

\footnotetext{
${ }^{11}$ Referring to the marginal effects reported in Table 2, this net effect is calculated as follows: $[(-0.0345)+(1.7 * 0.0070)]=-0.0226$.
} 
exposure, and earnings aren't significantly affected until high-pressure exposure reaches the 75th percentile.

[Figure 5 about here]

Appendix A contains the relative impact for each outcomes at different levels of total high-pressure exposure by demographic groups. The conclusions vary by outcome, but for the most part, even if the marginal effect of high-pressure exposure is statistically significant, the predicted outcome is not often significantly better than it would be with zero exposure.

\section{$\underline{5.3 \text { Impact of High-pressure Intensity vs. Duration }}$}

Periods of high-pressure differ in both their intensity and duration. The results from decomposing the effect of total high-pressure exposure into intensity and duration for the full sample are found in Table 3. Results by each demographic group can be found in Appendix B. The estimated high-unemployment impacts (seen in column 1) are similar to those reported in Table 2 (the specification that includes total high-pressure exposure rather than intensity and duration separately). The marginal effects of intensity and duration that are statistically significant at conventional levels are in bold.

\section{[Table 3 about here]}

Overall, for the full sample, more of the labor market outcomes benefit from more intense high-pressure vs. longer periods of high-pressure. These full-sample results, however, mask some differences across demographic groups (results seen in Appendix B). For example, the share of time spent unemployed by blacks, those with less than a high-school degree, and women benefit more from longer high-pressure periods than from more intense high-pressure. Additionally, the share of time spent unemployed by blacks and 18-24 year-olds, benefit from both longer and more intense periods of high-pressure. 
Loss of hourly pay being mitigated more by more intense high-pressure (vs. longer duration) and weekly hours benefiting more from longer periods of high-pressure is generally the pattern across demographic groups. These patterns are consistent with employers responding to more intense high-pressure periods along the extensive margin, but to longer high-pressure duration along the intensive margin. For example, in order to expand their workforce quickly during more intense high-pressure periods, employers need to bid up wages -- wage gains that appear to extend into the next high-unemployment period. Based on (Beaudry and DiNardo 1991) theory, this result is alternatively consistent with a wage determining mechanism dictated by contracts with costless mobility rather than by a spot market. Hourly pay of blacks, those in middle ages, the less educated, and males benefit more than their counterparts from intense highpressure.

However, in times of extended high-pressure periods (perhaps not as intense), employers are more likely to make labor force adjustments along the intensive margin by increasing hours of their existing workforce -- hours increases that carry over into the next high-unemployment period. Where statistically significant, the influence of high-pressure duration on mitigating hours losses is greater for blacks, Hispanics, the less educated, and females.

Of course, given that the adjustment on the intensive margin (wages) are concentrated on the experience of men and adjustment on the extensive margin (hours) are concentrated on the experience of women, there could be even more nuanced dynamics underlying these results.

\subsection{Outcomes During Low-unemployment periods}

Results that explore the extent to which the moderating effects of total high-pressure exposure reach beyond the following high-unemployment period into the next lowunemployment period are found in Table C1 in Appendix C. Generally, as we would expect, 
periods of low-unemployment are associated with less time spent unemployed, more time spent in the labor force, higher pay, and more hours of work. The moderating effect of exposure to an earlier high-pressure economy is weak, at best. For the full sample, only weekly hours significantly benefit from exposure, and by demographic group, the association often goes in the opposite direction than we might expect. So even if positive effects of exposure to a highpressure economy appears to reach into the following high-unemployment period, it doesn't appear to be able to reach into the next low-unemployment period.

\section{Sensitivity Analyses}

\subsection{Outcomes During Recessions}

While each labor market is somewhat unique across the country, downturns that are more widespread typically earn an official declaration of recession. To see whether labor market outcomes and the impact of high-pressure exposure on moderating those outcomes differs during these periods of common agony versus state-specific high-unemployment periods, the analysis described in equation (1) is repeated with an indicator for an NBER-declared recession, rather than the state-specific high-unemployment period. Results of this analysis are reported in Table $\mathrm{C} 2$ in Appendix C. Interpreting the results from this analysis are a bit problematic since multicollinearity necessitates dropping one year from the analysis in addition to the base year dummy. So, the marginal effects of a recession should be taken with a grain of salt (since they vary widely depending on which year is dropped), but the marginal effects of high-pressure exposure are not affected by which year is dropped. Overall, the pattern of results (negative impact of recessions and moderating effects of total high-pressure exposure) mirror those reported in Table 
2 with the moderating impact of high-pressure exposure more often statistically significant, but not necessarily larger.

\section{$\underline{6.2 \text { Excluding Individual Fixed Effects }}$}

Individual fixed effects are included in order to control for potential correlation between unobserved individual characteristics the extent to which high-pressure exposure moderates a person's labor market experience during high-unemployment periods. To see the degree to which this correlation might matter, the high-unemployment analysis is repeated excluding individual fixed-effects and results are reported in Table C3 in Appendix C. While qualitatively similar across demographic groups, the marginal effects are typically slightly larger, which is what we would expect if the individual fixed effect is picking up something unobserved that is correlated with both the outcome and exposure. Therefore, inclusion of individual fixed effects appears to be important in obtaining the impact of high-pressure exposure on labor market outcomes without confounding it with other, unobserved individual characteristics.

\section{$\underline{6.3 \text { Excluding Industry and Occupation Controls from Pay and Hours analyses }}$}

Some of the disparities between advantaged and disadvantaged demographic groups has been tied to the concentration of black and the low-skilled workers into certain occupations and/or industries (Bayer and Charles 2017; Cajner et al. 2017). The results in Table C4 in Appendix C illustrate that much of one's labor market experience (at least in wages and hours), across all demographic groups, derives from the particular occupation and industry in which one is employed. Both the impact of high-unemployment periods and the benefit of total highpressure exposure are quantitatively larger when industry and occupation are excluded from the regression. In other words, much of the variation in these outcomes across the business cycle is absorbed by the industry and occupation in which one is employed. Also note that the net effects 
(impact of high-unemployment period plus moderating effect of median high-pressure exposure) on both wage and hours are still worse for blacks and high-school graduates when occupation and industry are excluded as controls.

\section{$\underline{6.4}$ The Role of Migration}

One of the advantages of using longitudinal data is that we can see whether an individual was exposed to a high-pressure environment in a state different than the one in which he/she is experiencing the high-unemployment period. It was suggested that perhaps individuals could move in order to take advantage of high-pressure environments and any benefits that came with that exposure. Depending on the sample, there is anywhere from three percent (hourly pay and hours) to 22 percent (share of time spent unemployed and in the labor force) of observations that are in a different state at some point during the high-pressure exposure period than during the following high-unemployment period. Since we require non-zero wages and hours, it makes sense that there would be less mobility among those included in the hourly pay and hours

analyses. Results comparing those who migrated and those who did not can be found in Table C5 (share of time unemployed and time spent in the labor force) and Table C6 (hourly pay and weekly hours) in Appendix C. There are very few instances in which the moderating effect of high-pressure exposure is greater for those who changed states between that exposure and the high-unemployment experience. This suggests that migration is not playing a role in the relationship between high-pressure exposure and the more moderate labor market impacts of high-unemployment periods.

\section{Conclusions}

Evidence from the NLSY suggests that high-pressure labor markets during expansionary 
periods generate positive hysteresis by reducing time spent unemployed, increasing time in the labor force, and boosting hourly pay and hours in a following period of high-unemployment. The importance of intensity versus duration of the high-pressure period varies depending on the labor market outcome assessed. Regarding employer behavior, the results suggest that employers adjust their work force in response to more intense high-pressure periods along the extensive margin, raising wages (to attract workers) that last into the next high-unemployment period. Whereas employers adjust their work force along the intensive margin, increasing hours, in response to longer, but perhaps less intense, periods of high-pressure. We also find that benefits from exposure to high-pressure environments do not significantly extend beyond the highunemployment period into the next low-unemployment period, and that migrating does not necessarily improve one's outcome during high-unemployment periods.

Even though the advantages of a high-pressure economy can extend beyond the expansionary period for many different demographic groups, few demographic groups exposed to moderate levels of a high-pressure economy actually enjoy a predicted outcome significantly better than their counterparts with zero exposure. Additionally, while it is often the case that disadvantaged groups experience greater benefits from high-pressure exposure, the benefit (at median exposure levels) is typically not large enough to overcome the greater negative impact of the high-unemployment period experienced by disadvantaged groups. The implication is that moderate periods of high-pressure environments are not likely to greatly improve labor market outcome gaps. Consequently, as a tool for reducing labor market gaps, extending a high-pressure economic environment is not likely to be efficacious. 


\section{References}

Abraham, K. G., and Haltiwanger, J. C. (1995), "Real Wages and the Business Cycle," Journal of Economic Literature, 33, 1215-1264. https://doi.org/10.2307/2729121.

Antecol, H., and Bedard, K. (2004), "The Racial Wage Gap," Journal of Human Resources, 39, 564.

Arnold, R. (2008), Reestimating the Phillips Curve and the NAIRU, Working Paper, Washington, D.C.: Congressional Budget Office.

Atkeson, A., and Ohanian, L. E. (2001), “Are Phillips curves useful for forecasting inflation?," Federal Reserve Bank of Minneapolis. Quarterly Review - Federal Reserve Bank of Minneapolis, 25, 211.

Bayer, P., and Charles, K. K. (2017), Divergent Paths: Structural Change, Economic Rank, and the Evolution of Black-White Earnings Differences, 1940-2014, Working Paper, National Bureau of Economic Research. https://doi.org/10.3386/w22797.

Beaudry, P., and DiNardo, J. (1991), "The Effect of Implicit Contracts on the Movement of Wages Over the Business Cycle: Evidence from Micro Data," Journal of Political Economy, 99, 665-688. https://doi.org/10.1086/261774.

Biddle, J. E., and Hamermesh, D. S. (2013), "Wage discrimination over the business cycle," IZA Journal of Labor Policy; Heidelberg, 2, 1-19. http://dx.doi.org.ezproxy.gsu.edu/10.1186/2193-9004-2-7.

Bradbury, K. L. (2000), "Rising tide in the labor market: To what degree do expansions benefit the disadvantaged?," New England Economic Review; Boston, 3-33.

Cajner, T., Radler, T., Ratner, D., and Vidangos, I. (2017), Racial Gaps in labor market Outcomes in the Last Four Decades and over the Business Cycle, Finance and Economics Discussion Series, Working Paper, Washington, D.C.: Federal Reserve Board.

Carneiro, A., Guimarães, P., and Portugal, P. (2012), "Real Wages and the Business Cycle: Accounting for Worker, Firm, and Job Title Heterogeneity," American Economic Journal: Macroeconomics, 4, 133-152. https://doi.org/10.1257/mac.4.2.133.

CBO (1994), "Appendix B: Reestimating the NAIRU," in The Economic and Budget Outlook: An Update, Washington, D.C.: Congressional Budget Office, pp. 59-62.

Chetty, R., Hendren, N., Jones, M. R., and Porter, S. R. (2018), Race and Economic Opportunity in the United States: An Intergenerational Perspective, Mimeo, , p. 106.

Cockx, B., and Ghirelli, C. (2016), "Scars of recessions in a rigid labor market," Labour Economics, SOLE/EALE conference issue 2015, 41, 162-176. https://doi.org/10.1016/j.labeco.2016.05.009.

Condon, C., and Torres, C. (2016), "Fed's Rosengren Says Economy Already Headed for Hot Labor Market," Bloomberg.com.

Couch, K. A., and Fairlie, R. (2010), "Last hired, first fired? black-white unemployment and the business cycle," Demography, 47, 227-247. https://doi.org/10.1353/dem.0.0086.

Devereux, P. J., and Hart, R. A. (2007), "The Spot Market Matters: Evidence on Implicit Contracts from Britain," Scottish Journal of Political Economy, 54, 661-683. https://doi.org/10.1111/j.14679485.2007.00435.x.

Ellwood, D. T. (1982), "Teenage Unemployment: Permanent Scars or Temporary Blemishes?,” in The Youth Labor Market Problem: Its Nature, Causes, and Consequences, eds. R. B. Freeman and D. A. Wise, Chicago, IL: University Of Chicago Press, pp. 349-390.

Engemann, K. M., and Wall, H. J. (2010), The Effects of Recessions Across Demographic Groups, Federal Reserve Bank of St. Louis.

Fallick, B., and Krolikowski, P. (2018), Hysteresis in Employment among Disadvantaged Workers, Working Paper, Cleveland, Ohio: Federal Reserve Bank of Cleveland.

Fernández-Kranz, D., and Rodríguez-Planas, N. (2018), "The Perfect Storm: Graduating during a Recession in a Segmented Labor Market," ILR Review, 71, 492-524. https://doi.org/10.1177/0019793917714205. 
Fischer, S. (2016), "Why Are Interest Rates So Low? Causes and Implications," Board of Governors of the Federal Reserve System, Speeches, Speech transcript, , Available athttps://www.federalreserve.gov/newsevents/speech/fischer20161017a.htm.

Fisher, I. (1926), “A Statistical Relation between Unemployment and Price Changes," International Economic Review, (reprinted as "I discovered the Phillips Curve." Journal of Political Economy 81 (March/April 1973): 496-502), 13, 496-502.

Fleischman, C. A., and Gallin, J. H. (2001), Employment persistence, Finance and Economics Discussion Series, Board of Governors of the Federal Reserve System (U.S.).

Gordon, R. J. (2011), "The History of the Phillips Curve: Consensus and Bifurcation," Economica, 78, 10-50. https://doi.org/10.1111/j.1468-0335.2009.00815.x.

Hall, R. E. (1970), "Why Is the Unemployment Rate So High at Full Employment?," Brookings Papers on Economic Activity, 1, 369-402.

Holzer, H. J., Raphael, S., and Stoll, M. A. (2006), "Employers in the Boom: How Did the Hiring of Less-Skilled Workers Change during the 1990s?," The Review of Economics and Statistics, 88, 283-299.

Hotchkiss, J. L. (1991), “A time series analysis of disaggregate U.S. unemployment,” Journal of Macroeconomics, 13, 701-711. https://doi.org/10.1016/S0164-0704(05)80021-7.

Hoynes, H., Miller, D. L., and Schaller, J. (2012), "Who Suffers During Recessions?," The Journal of Economic Perspectives, 26, 27-47.

Jefferson, P. N. (2005), "Does Monetary Policy Affect Relative Educational Unemployment Rates?," American Economic Review, 95, 76-82.

Jefferson, P. N. (2008), "Educational Attainment and the Cyclical Sensitivity of Employment," Journal of Business \& Economic Statistics, 26, 526-535. https://doi.org/10.1198/073500108000000060.

Kahn, L. B. (2010), "The long-term labor market consequences of graduating from college in a bad economy," Labour Economics, 17, 303-316.

King, R. G., and Watson, M. W. (1994), "The post-war U.S. phillips curve: a revisionist econometric history," Carnegie-Rochester Conference Series on Public Policy, 41, 157-219. https://doi.org/10.1016/0167-2231(94)00018-2.

Kondo, A. (2015), "Differential effects of graduating during a recession across gender and race," IZA Journal of Labor Economics; Heidelberg, 4, 1-24. http://dx.doi.org.ezproxy.gsu.edu/10.1186/s40172-015-0040-6.

Krause, M. U., and Lubik, T. A. (2006), "The cyclical upgrading of labor and on-the-job search," Labour Economics, Special Issue: European Association of Labour Economists, 2nd World Conference SOLE/EALE, Fairmont Hotel San Francisco, USA, 2-5 June 2005, 13, 459-477. https://doi.org/10.1016/j.labeco.2006.02.007.

Liu, K., Salvanes, K. G., and Sørensen, E. Ø. (2016), "Good skills in bad times: Cyclical skill mismatch and the long-term effects of graduating in a recession," European Economic Review, European Labor Market Issues, 84, 3-17. https://doi.org/10.1016/j.euroecorev.2015.08.015.

Lucas, R. E., and Sargent, T. J. (1978), "After Keynesian Macroeconomics," in After The Phillips Curve: Persistence of High Inflation and High Unemployment, Boston, MA, p. 63.

Maclean, J. C. (2013), "The health effects of leaving school in a bad economy," Journal of Health Economics, 32, 951-964. https://doi.org/10.1016/j.jhealeco.2013.07.003.

Maclean, J. C., and Hill, T. D. (2015), "Leaving school in an economic downturn and self-esteem across early and middle adulthood," Labour Economics, 37, 1-12. https://doi.org/10.1016/j.labeco.2015.08.004.

Martins, P. S., Solon, G., and Thomas, J. P. (2012), "Measuring What Employers Do about Entry Wages over the Business Cycle: A New Approach," American Economic Journal: Macroeconomics, 4, 36-55. https://doi.org/10.1257/mac.4.4.36.

Okun, A. M. (1973), "Upward Mobility in a High-Pressure Economy," Brookings Papers on Economic Activity, 1. 
Oreopoulos, P., von Wachter, T., and Heisz, A. (2012), "The Short-and Long-Term Career Effects of Graduating in a Recession," American Economic Journal: Applied Economics, 4, 1-29.

Otrok, C., and Pourpourides, P. M. (2017), "On the cyclicality of real wages and wage differentials," The B.E. Journal of Macroeconomics, 0. https://doi.org/10.1515/bejm-2017-0047.

Perry, G. L. (1970), "Changing Labor Markets and Inflation," Brookings Papers on Economic Activity, 1, 411-441.

Phillips, A. W. (1958), "The Relation Between Unemployment and the Rate of Change of Money Wage Rates in the United Kingdom, 1861-19571," Economica, 25, 283-299. https://doi.org/10.1111/j.1468-0335.1958.tb00003.x.

Rose, A. K., Akerlof, G. A., and Yellen, J. L. (1988), "Job Switching and Job Satisfaction in the U.S. Labor Market," Brookings, 495-582.

Schmieder, J. F., and von Wachter, T. (2010), "Does Wage Persistence Matter for Employment Fluctuations? Evidence from Displaced Workers," American Economic Journal: Applied Economics, 2, 1-21. https://doi.org/10.1257/app.2.3.1.

Schmillen, A., and Umkehrer, M. (2017), "The scars of youth: Effects of early-career unemployment on future unemployment experience," International Labour Review, 156, 465-494. https://doi.org/10.1111/ilr.12079.

von Wachter, T., and Bender, S. (2006), "In the Right Place at the Wrong Time: The Role of Firms and Luck in Young Workers' Careers," The American Economic Review, 96, 1679-1705.

Walden, M. L. (2012), "Explaining Differences in State Unemployment Rates During the Great Recession," Journal of Regional Analysis \& Policy, 43, 251-57.

Yagan, D. (2017), Employment Hysteresis from the Great Recession, Working Paper, National Bureau of Economic Research. https://doi.org/10.3386/w23844.

Zavodny, M., and Zha, T. (2000), "Monetary policy and racial unemployment rates," Federal Reserve Bank of Atlanta Economic Review, 85, 1-59. 
Figure 1. Actual and natural rate of unemployment with indicator of high-pressure total exposure for North Dakota and Mississippi.

(a) North Dakota

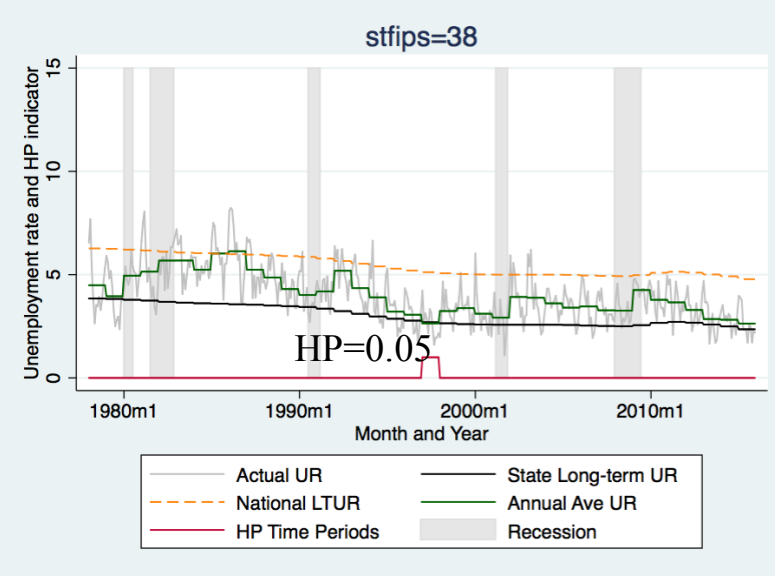

(b) Mississippi

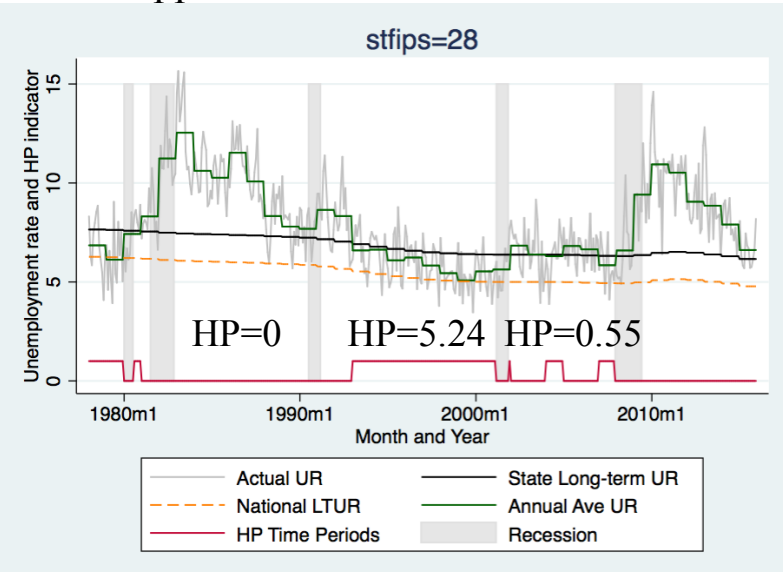

Figure 2. Oldest and youngest ages from each NLSY survey by year.

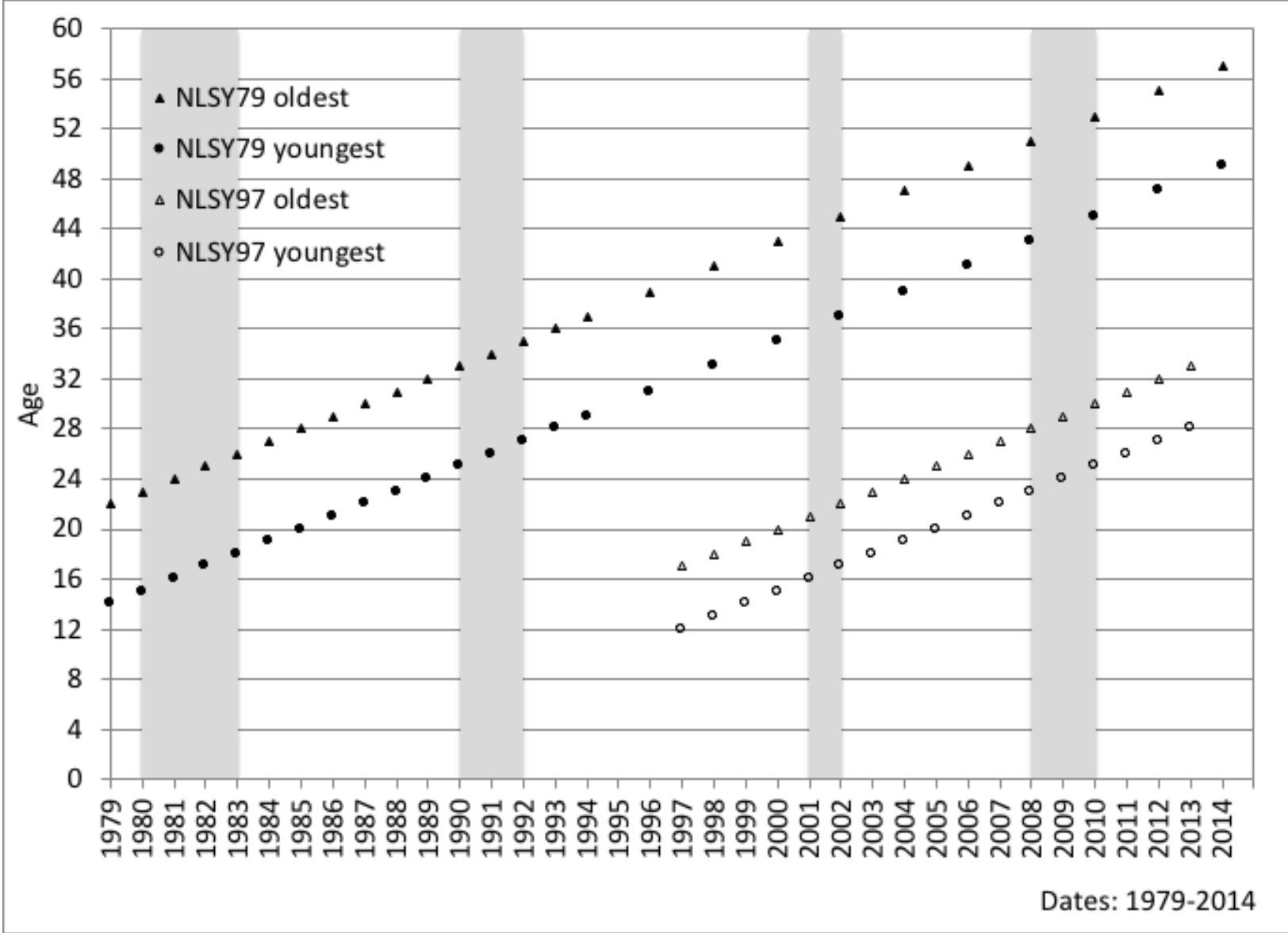

Note: Recessionary years shaded in gray. 
Figure 3. Average share of time spent unemployed during high- and low-unemployment periods by demographic group.

(a) By Race

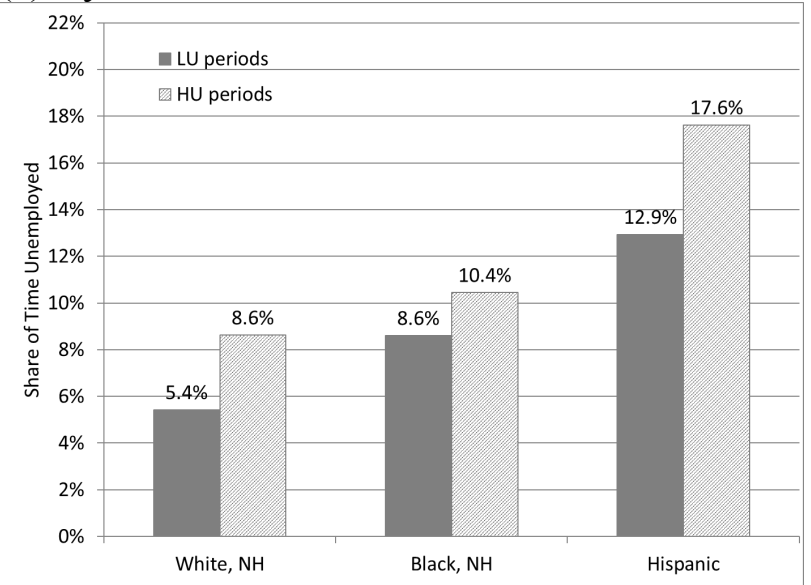

(c) By Education

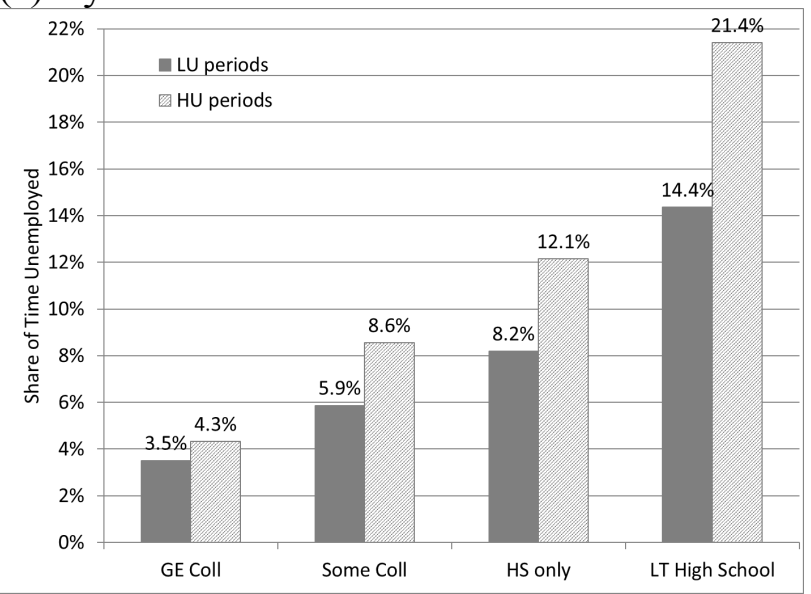

(b) By Age

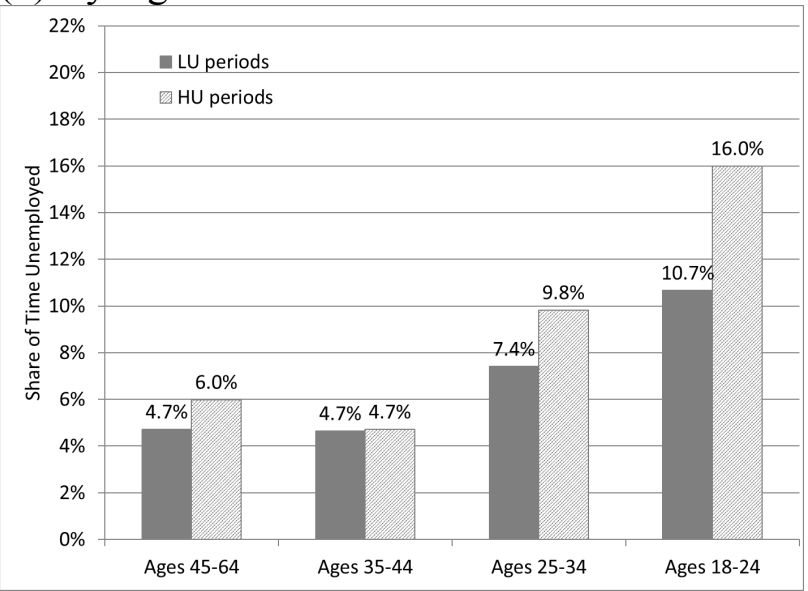

(d) By Gender

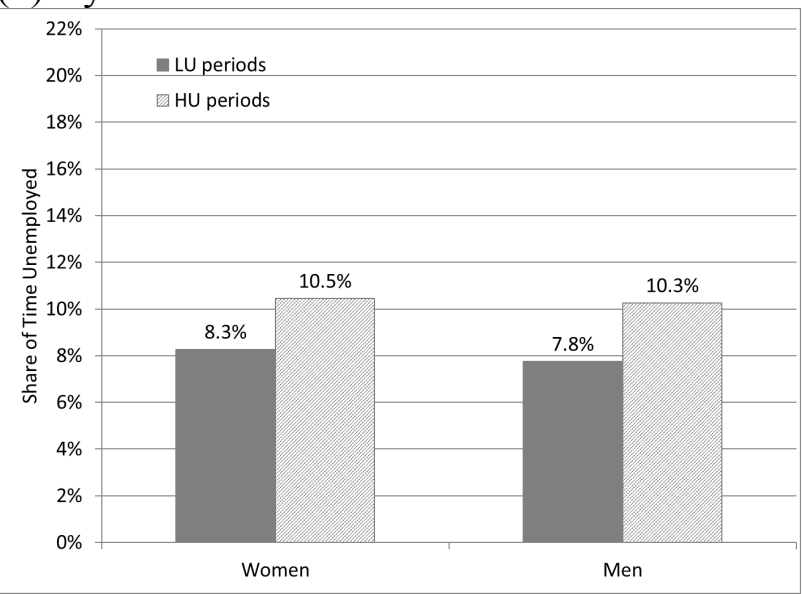

Notes: Data source is the NLSY (1979 and 1997). Means for those with non-zero employment during expansions. Racial groups other than "Black" are not distinguished in the 1979 cohort so are combined with "White" for the full sample. High- (low-) unemployment periods are those in which the state's unemployment rate falls above (below) the state's LTUR. Construction of a state's LTUR is described in Section 2. 
Figure 4. Average hourly pay during high- and low-unemployment periods by demographic group.

(a) By Race

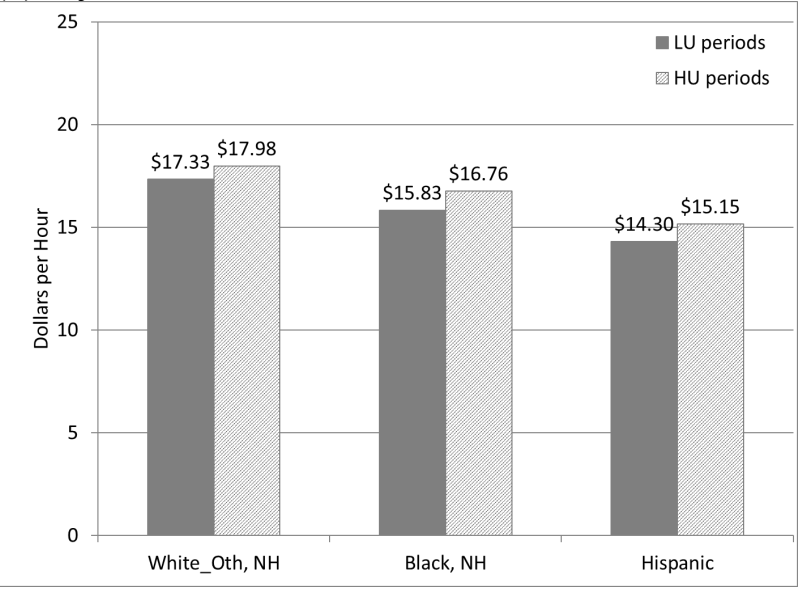

(c) By Education

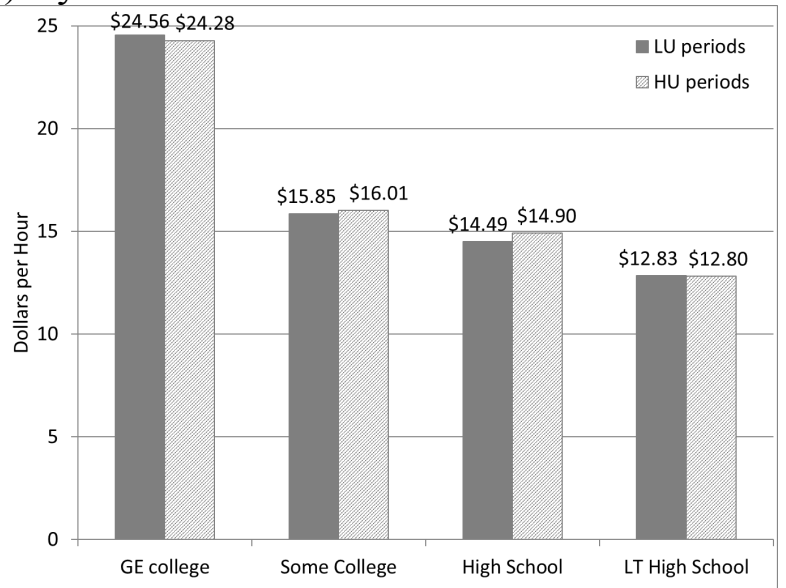

(b) By Age

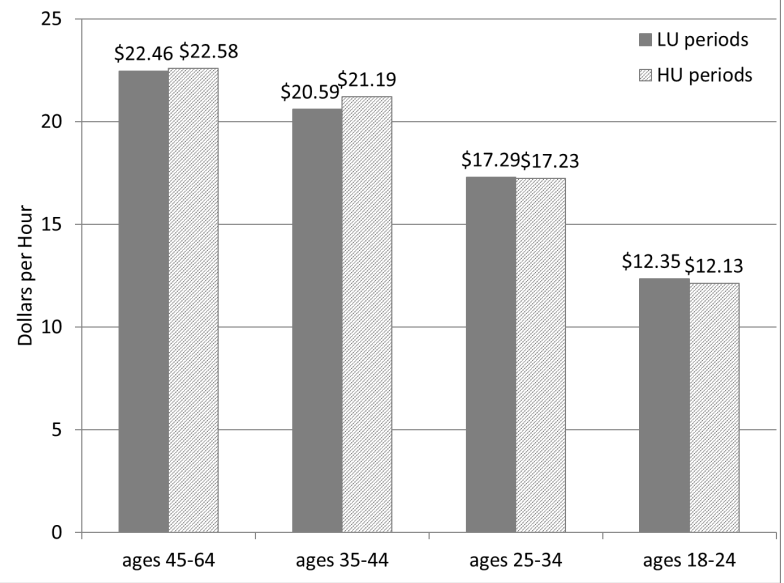

(d) By Gender

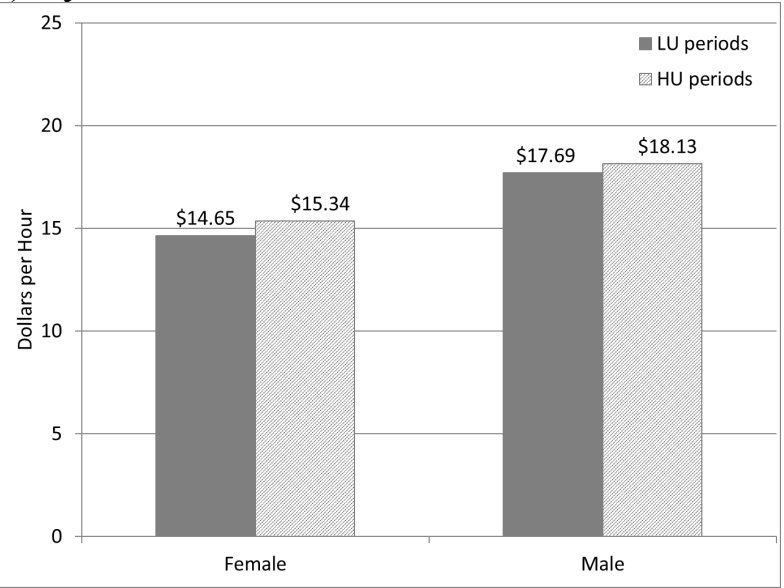

Notes: Data source is the NLSY (1979 and 1997). Means over workers only, excluding bottom and top one percent of wage earners and those reporting a wage of less than one dollar per hour; real values in 2014 dollars. Racial groups other than "Black" are not distinguished in the 1979 cohort so are combined with "White" for the full sample. High- (low-) unemployment periods are those in which the state's unemployment rate falls above (below) the state's LTUR. Construction of a state's LTUR is described in Section 2. 
Figure 5. Predicted outcome during high-unemployment periods for each outcome at the 25th percentile, median, and 75th percentile levels of total high-pressure exposure, full sample only.

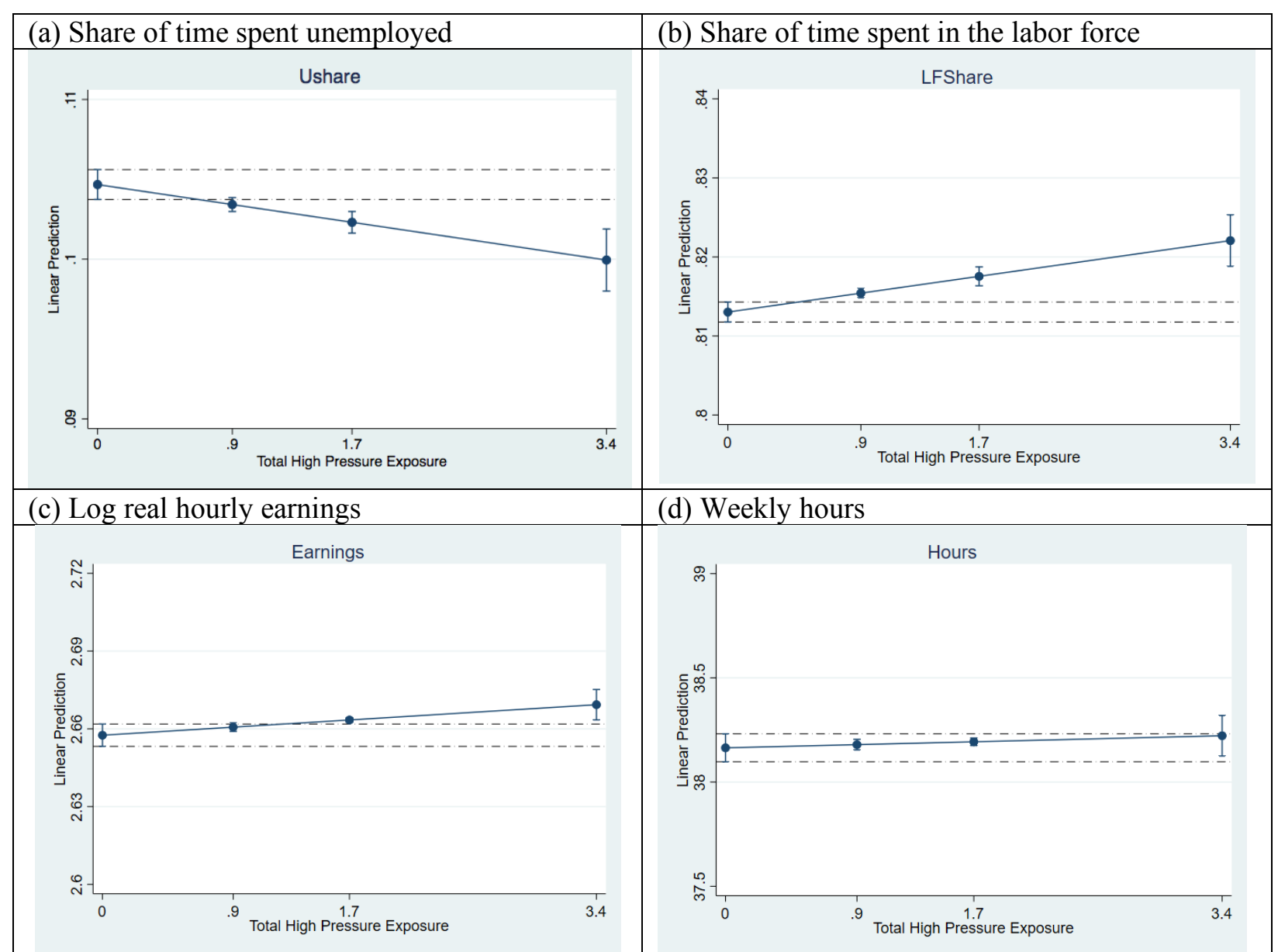

Note: Graphs for each demographic group separately are found in Appendix A. 
Table 1. Unweighted sample means of NLSY by cohort and age group.

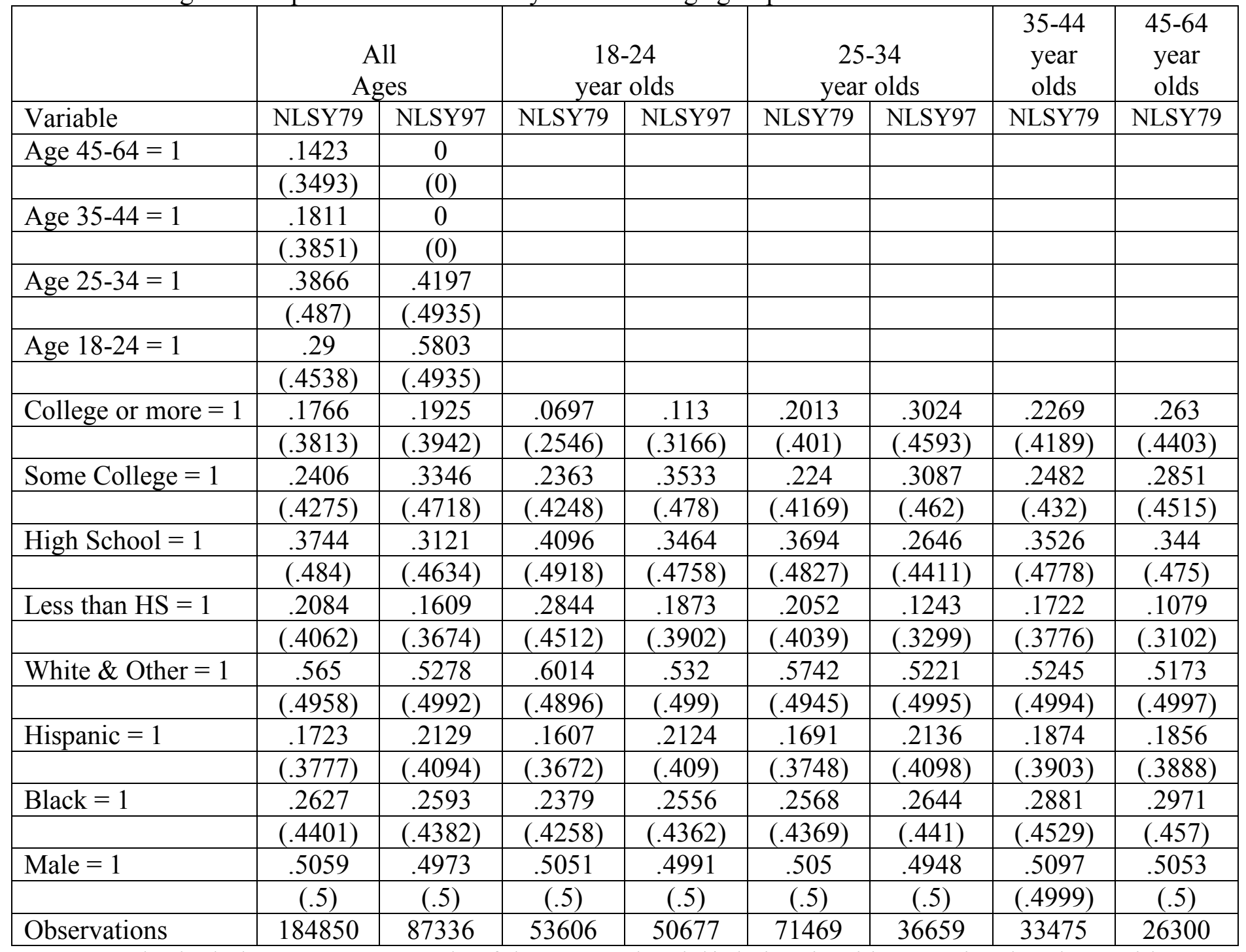

Note: Samples include NLSY oversample of the poor and racial/ethnic minorities; restricted to those with nonzero employment during expansions. Standard deviations in parentheses. Racial groups other than "Black" are not distinguished in the 1979 cohort so are combined with "White" for the full sample. 
Table 2. Marginal effect of the impact of high-unemployment periods and total high-pressure exposure on labor market outcomes, by demographic groups.

\begin{tabular}{|c|c|c|c|c|c|c|c|c|}
\hline & \multicolumn{2}{|c|}{$\begin{array}{c}\text { Share of time spent } \\
\text { unemployed }\end{array}$} & \multicolumn{2}{|c|}{$\begin{array}{l}\text { Share of time spent } \\
\text { in the labor force }\end{array}$} & \multicolumn{2}{|c|}{$\begin{array}{c}\text { Log real } \\
\text { hourly pay }\end{array}$} & \multicolumn{2}{|c|}{$\begin{array}{l}\text { Weekly } \\
\text { hours }\end{array}$} \\
\hline & $\begin{array}{c}\text { Marginal } \\
\text { effect of } \\
\text { high unempl. } \\
\text { dUshare }\end{array}$ & $\begin{array}{l}\text { Marginal effect } \\
\text { of HP exposure } \\
\text { oUshare }\end{array}$ & 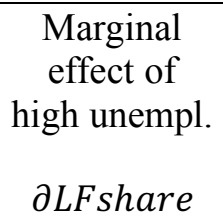 & $\begin{array}{l}\text { Marginal effect } \\
\text { of HP exposure } \\
\text { oLFshare }\end{array}$ & $\begin{array}{c}\text { Marginal } \\
\text { effect of } \\
\text { high unempl. } \\
\text { dlnW }\end{array}$ & $\begin{array}{l}\text { Marginal effect } \\
\text { of HP exposure } \\
\qquad \ln W\end{array}$ & $\begin{array}{c}\text { Marginal } \\
\text { effect of } \\
\text { high unempl. } \\
\text { дHrs }\end{array}$ & $\begin{array}{l}\text { Marginal } \\
\text { effect of HP } \\
\text { exposure } \\
\text { дHrs }\end{array}$ \\
\hline & $\partial H U$ & $\left.\overline{\partial H P s u m}\right|_{H U=1}$ & $\partial H U$ & $\left.\overline{\partial H P s u m}\right|_{H U=1}$ & $\overline{\partial H U}$ & $\left.\overline{\partial H P s u m}\right|_{H U=1}$ & $\overline{\partial H U}$ & $\left.\overline{\partial H P s u m}\right|_{H U=1}$ \\
\hline \multirow[t]{2}{*}{ Full Sample } & $0.0121^{* * *}$ & $-0.0014^{* * *}$ & -0.0003 & $0.0027^{* * *}$ & $-0.0219^{* * *}$ & $0.0035^{*}$ & $-0.2847^{* *}$ & 0.017 \\
\hline & {$[0.0025]$} & {$[0.0004]$} & {$[0.0046]$} & {$[0.0006]$} & {$[0.0036]$} & {$[0.0015]$} & {$[0.1090]$} & {$[0.0245]$} \\
\hline \multirow[t]{2}{*}{ Ages 45-57 } & $-0.0188^{*}$ & -0.0012 & -0.0034 & 0.0004 & $-0.0427^{* * *}$ & $0.0057^{* *}$ & $-0.9066^{*}$ & 0.0527 \\
\hline & {$[0.0085]$} & {$[0.0012]$} & {$[0.0085]$} & {$[0.0013]$} & {$[0.0109]$} & {$[0.0019]$} & {$[0.3787]$} & {$[0.0403]$} \\
\hline \multirow[t]{2}{*}{ Ages 35-44 } & 0.003 & $-0.0012^{*}$ & 0.0046 & -0.001 & $-0.0238^{* * *}$ & 0.0034 & $-0.7049^{* * *}$ & 0.012 \\
\hline & {$[0.0045]$} & {$[0.0005]$} & {$[0.0064]$} & {$[0.0011]$} & {$[0.0044]$} & {$[0.0018]$} & {$[0.1980]$} & {$[0.0343]$} \\
\hline \multirow[t]{2}{*}{ Ages 25-34 } & $0.0139^{* * *}$ & -0.0001 & 0.009 & -0.0001 & -0.0143 & $0.0051^{*}$ & 0.0693 & -0.0693 \\
\hline & {$[0.0026]$} & {$[0.0007]$} & {$[0.0048]$} & {$[0.0009]$} & {$[0.0076]$} & {$[0.0024]$} & [0.2149] & {$[0.0448]$} \\
\hline \multirow[t]{2}{*}{ Ages 18-24 } & $0.0193^{* * * *}$ & $-0.0045^{* * *}$ & -0.0064 & $0.0098^{* * * *}$ & $-0.0195^{* * *}$ & 0.005 & -0.0997 & 0.1252 \\
\hline & {$[0.0037]$} & {$[0.0013]$} & {$[0.0058]$} & {$[0.0026]$} & {$[0.0049]$} & {$[0.0032]$} & {$[0.0910]$} & {$[0.0697]$} \\
\hline \multirow[t]{2}{*}{ White, NH } & $0.0073^{*}$ & 0.0006 & 0.0046 & 0.0012 & $-0.0196^{* * *}$ & 0.0043 & -0.0895 & -0.0232 \\
\hline & {$[0.0029]$} & {$[0.0005]$} & {$[0.0045]$} & {$[0.0009]$} & {$[0.0042]$} & {$[0.0022]$} & {$[0.1259]$} & {$[0.0340]$} \\
\hline \multirow[t]{2}{*}{ Hispanic } & -0.0004 & -0.0014 & 0.0052 & $0.0040^{*}$ & $-0.0116^{*}$ & 0.0034 & $-0.3325^{*}$ & 0.0399 \\
\hline & {$[0.0027]$} & {$[0.0009]$} & {$[0.0068]$} & {$[0.0017]$} & {$[0.0052]$} & {$[0.0031]$} & {$[0.1604]$} & {$[0.0752]$} \\
\hline \multirow[t]{2}{*}{ Black, NH } & $0.0313^{* * *}$ & $-0.0081^{* * *}$ & $-0.0147^{* *}$ & $0.0084^{* * *}$ & $-0.0345^{* * *}$ & $0.0070^{* *}$ & $-0.6591^{* * *}$ & $0.1498^{* *}$ \\
\hline & {$[0.0043]$} & {$[0.0013]$} & {$[0.0054]$} & {$[0.0015]$} & {$[0.0068]$} & {$[0.0022]$} & {$[0.1400]$} & {$[0.0518]$} \\
\hline \multirow[t]{2}{*}{ GE College } & $-0.0077^{* *}$ & 0.0003 & 0.004 & $0.0043^{*}$ & 0.0179 & -0.0004 & $0.7621^{* * *}$ & $-0.0781^{*}$ \\
\hline & {$[0.0029]$} & {$[0.0005]$} & {$[0.0064]$} & {$[0.0019]$} & {$[0.0101]$} & {$[0.0013]$} & {$[0.2457]$} & {$[0.0372]$} \\
\hline \multirow[t]{2}{*}{ Some College } & 0.0047 & 0.0007 & -0.0054 & $0.0032^{* * *}$ & $-0.0269^{* * *}$ & $0.0085^{* *}$ & $-0.3446^{*}$ & 0.0149 \\
\hline & {$[0.0030]$} & {$[0.0008]$} & {$[0.0051]$} & {$[0.0007]$} & {$[0.0058]$} & {$[0.0032]$} & {$[0.1582]$} & {$[0.0345]$} \\
\hline \multirow[t]{2}{*}{ High School } & $0.0135^{* * *}$ & $-0.0024^{* *}$ & 0.0056 & $0.0033^{* *}$ & $-0.0378^{* * *}$ & $0.0069^{*}$ & $-0.7883^{* * *}$ & 0.0886 \\
\hline & {$[0.0026]$} & {$[0.0008]$} & {$[0.0051]$} & {$[0.0011]$} & {$[0.0056]$} & {$[0.0028]$} & {$[0.1543]$} & {$[0.0526]$} \\
\hline \multirow[t]{2}{*}{ LT High School } & $0.0394^{* * *}$ & $-0.0078^{* * *}$ & -0.0084 & $0.0043^{*}$ & $-0.0289^{* * * *}$ & 0.0002 & $-0.4369^{* * *}$ & 0.1023 \\
\hline & {$[0.0050]$} & {$[0.0013]$} & {$[0.0068]$} & {$[0.0018]$} & {$[0.0084]$} & {$[0.0025]$} & {$[0.1320]$} & {$[0.1023]$} \\
\hline
\end{tabular}




\begin{tabular}{|c|c|c|c|c|c|c|c|c|}
\hline & \multicolumn{2}{|c|}{$\begin{array}{c}\text { Share of time spent } \\
\text { unemployed }\end{array}$} & \multicolumn{2}{|c|}{$\begin{array}{l}\text { Share of time spent } \\
\text { in the labor force }\end{array}$} & \multicolumn{2}{|c|}{$\begin{array}{c}\text { Log real } \\
\text { hourly pay }\end{array}$} & \multicolumn{2}{|c|}{$\begin{array}{c}\text { Weekly } \\
\text { hours }\end{array}$} \\
\hline & 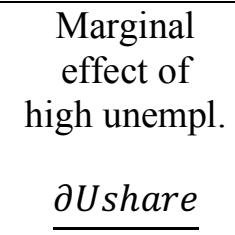 & $\begin{array}{l}\text { Marginal effect } \\
\text { of HP exposure } \\
\text { oUshare }\end{array}$ & 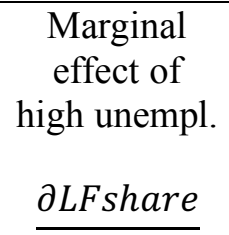 & $\begin{array}{l}\text { Marginal effect } \\
\text { of HP exposure } \\
\text { oLFshare }\end{array}$ & 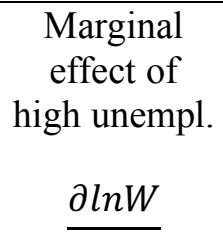 & $\begin{array}{l}\text { Marginal effect } \\
\text { of HP exposure } \\
\partial \ln W \\
\end{array}$ & $\begin{array}{c}\text { Marginal } \\
\text { effect of } \\
\text { high unempl. } \\
\underline{\partial H r s}\end{array}$ & $\begin{array}{l}\text { Marginal } \\
\text { effect of HP } \\
\text { exposure } \\
\text { oHrs }\end{array}$ \\
\hline & $\partial H U$ & $\left.\overline{\partial H P s u m}\right|_{H U=1}$ & $\partial H U$ & $\left.\overline{\partial H P s u m}\right|_{H U=1}$ & $\overline{\partial H U}$ & $\left.\overline{\partial H P s u m}\right|_{H U=1}$ & $\overline{\partial H U}$ & $\left.\overline{\partial H P s u m}\right|_{H U=1}$ \\
\hline Females & $0.0126^{* * *}$ & $-0.0026^{* * *}$ & -0.0022 & $0.0032^{* *}$ & $-0.0138^{* *}$ & 0.0027 & -0.2186 & 0.024 \\
\hline & {$[0.0029]$} & {$[0.0006]$} & {$[0.0046]$} & {$[0.0010]$} & {$[0.0043]$} & {$[0.0023]$} & {$[0.1285]$} & {$[0.0365]$} \\
\hline Males & $0.0117^{* * * *}$ & $-0.0014^{*}$ & 0.0015 & $0.0041^{* *}$ & $-0.0296^{* * *}$ & $0.0069^{* *}$ & $-0.3465^{* *}$ & 0.0433 \\
\hline & {$[0.0028]$} & {$[0.0007]$} & {$[0.0055]$} & {$[0.0014]$} & {$[0.0037]$} & {$[0.0023]$} & {$[0.1340]$} & {$[0.0578]$} \\
\hline Observations & 253,186 & & 272,186 & & 146,556 & & 155,015 & \\
\hline
\end{tabular}

Notes: Data source is the National Longitudinal Survey of Youth (1979 and 1997). Robust standard errors, in brackets, are clustered at the state level; *** $\mathrm{p}<0.01,{ }^{*} \mathrm{p}<0.05, * \mathrm{p}<0.1$. All regressions include year, state, and individual fixed effects. Hourly pay and weekly hours regressions include controls for occupation and industry. Regressions include the NLSY oversample of the poor and racial/ethnic minorities. Sample is restricted to individual who had nonzero employment during expansionary periods, positive wage (for log real hourly pay analysis), and positive hours (for weekly hours analysis). Statistically significant moderation of the impact of high unemployment periods from high-pressure exposure are indicated in bold. 
Table 3. Marginal effect of high-unemployment periods and high-pressure intensity and high-pressure duration on each outcome, full sample only

\begin{tabular}{|c|c|c|c|}
\hline Outcome & $\begin{array}{l}\text { Marginal effect } \\
\text { of high } \\
\text { unemployment } \\
\frac{\partial u s h a r e}{\partial H U}\end{array}$ & $\begin{array}{l}\text { Marginal effect } \\
\text { of average HP } \\
\text { intensity } \\
\left.\frac{\partial U \text { share }}{\partial H P a v g}\right|_{H U=1}\end{array}$ & $\begin{array}{c}\begin{array}{c}\text { Marginal } \\
\text { effect of HP } \\
\text { duration }\end{array} \\
\left.\frac{\partial U \text { share }}{\partial H P n}\right|_{H U=1}\end{array}$ \\
\hline $\begin{array}{l}\text { Share of time spent unemployed } \\
N=253,186\end{array}$ & $\begin{array}{l}0.0127^{* * *} \\
{[0.0025]}\end{array}$ & $\begin{array}{c}\mathbf{- 0 . 0 0 9 7}^{* *} \\
{[0.0034]}\end{array}$ & $\begin{array}{l}-0.0003 \\
{[0.0007]}\end{array}$ \\
\hline $\begin{array}{l}\text { Share of time spent in the labor force } \\
N=272,186\end{array}$ & $\begin{array}{l}-0.0008 \\
{[0.0049]}\end{array}$ & $\begin{array}{l}\mathbf{0 . 0 1 3 0}^{*} \\
{[0.0054]}\end{array}$ & $\begin{array}{c}0.0019 \\
{[0.0011]}\end{array}$ \\
\hline $\begin{array}{l}\text { Log hourly pay } \\
\mathrm{N}=146,556\end{array}$ & $\begin{array}{c}-0.0269^{* * *} \\
{[0.0039]}\end{array}$ & $\begin{array}{l}\mathbf{0 . 0 2 6 2} 2^{* *} \\
{[0.0088]}\end{array}$ & $\begin{array}{c}0.001 \\
{[0.0012]}\end{array}$ \\
\hline $\begin{array}{l}\text { Weekly hours } \\
N=155,015\end{array}$ & $\begin{array}{c}-0.4290^{* * *} \\
{[0.1202]}\end{array}$ & $\begin{array}{c}0.0397 \\
{[0.2164]}\end{array}$ & $\begin{array}{l}\mathbf{0 . 1 0 7 8}^{* *} \\
{[0.0334]}\end{array}$ \\
\hline
\end{tabular}

Notes: Data source is the National Longitudinal Survey of Youth (1979 and 1997). Robust standard errors, in brackets, are clustered at the state level; *** $\mathrm{p}<0.01, * * \mathrm{p}<0.05, * \mathrm{p}<0.1$. All regressions include year, state, and individual fixed effects. Regressions include the NLSY oversample of the poor and racial/ethnic minorities. Sample is restricted to individual who had nonzero employment during expansionary periods and non-zero wages and hours for the wage and hours analyses. Results by demographic groups are found in Appendix A. Statistically significant moderation of the impact of high unemployment periods from high-pressure exposure are indicated in bold. 


\section{SUPPLEMENTAL APPENDICES}

Additional Tables and Figures

for

Some Like it Hot: Assessing Longer-term Labor Market

Benefits from a High-Pressure Economy 
Appendix A. Predicted outcome during high-unemployment periods at the 25th percentile, median, and 75th percentile levels of total high-pressure exposure, by demographic group.

Table A1. Time spent unemployed.

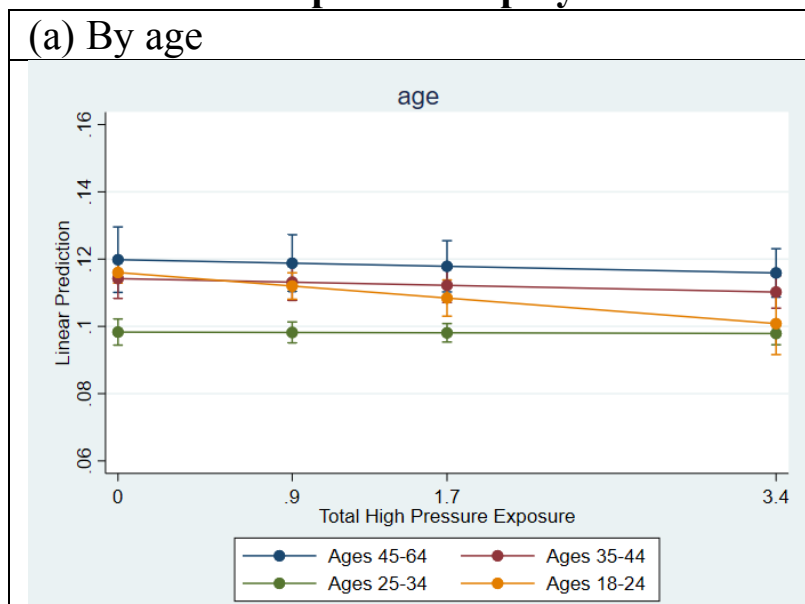

Time spent unemployed by 18-24 year-olds with at least median high-pressure exposure is significantly higher than the same group with zero exposure.

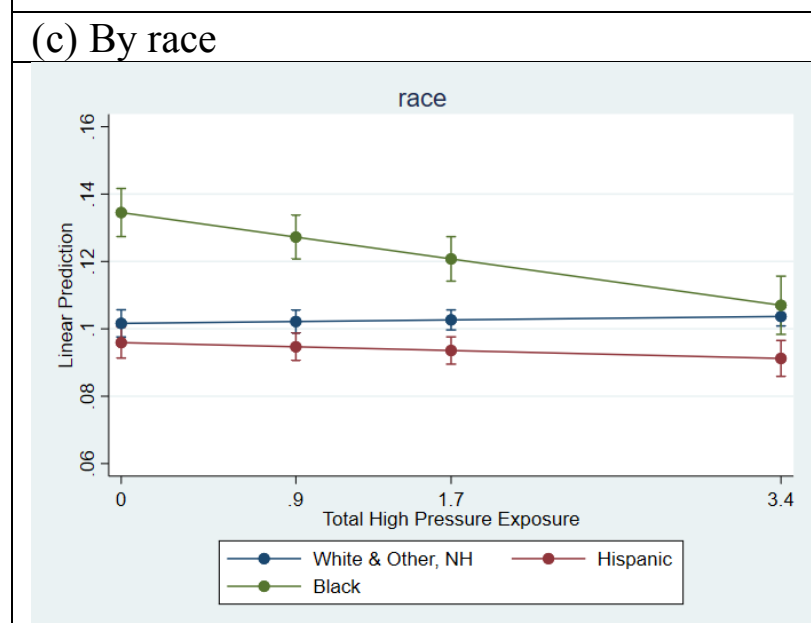

Time spent unemployed by Hispanics and Blacks with at least median high-pressure exposure is significantly higher than the same group with zero exposure. (b) By education

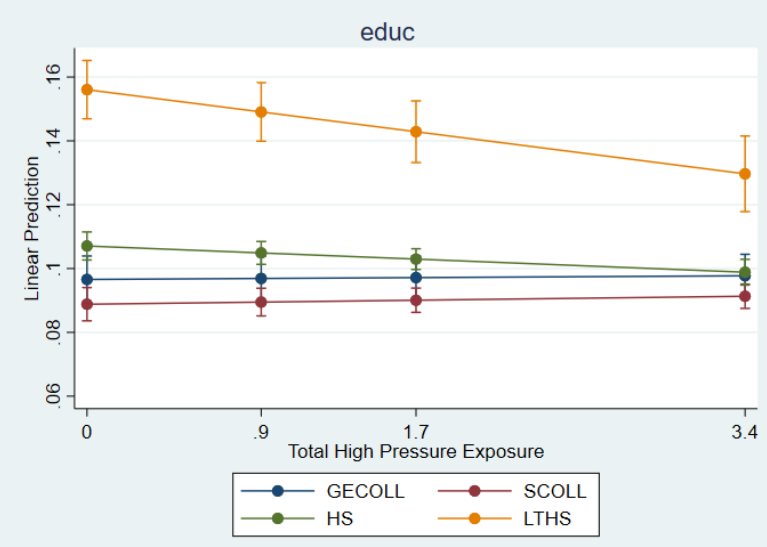

Time spent unemployed by those with a high school degree or less with total high-pressure exposure of at least the 75th percentile is significantly lower than those with zero exposure.

(d) By sex

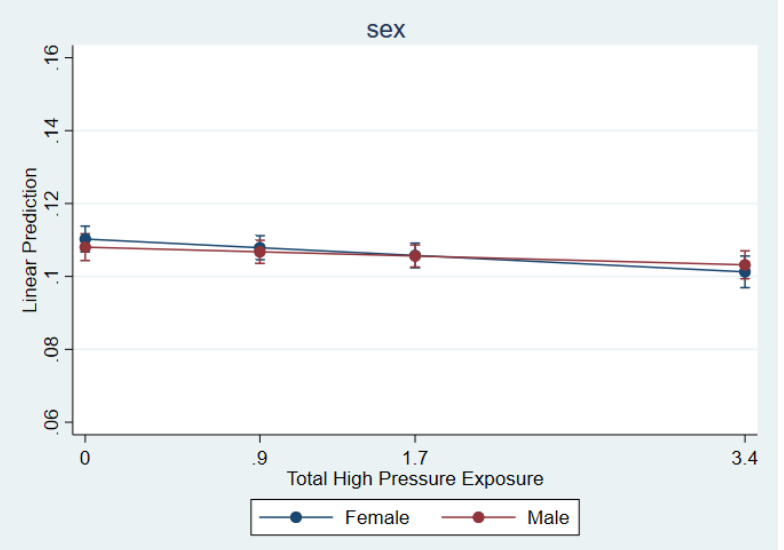

Time spent unemployed by men (women) with total high-pressure exposure of at least the median (75th percentile) is significantly lower than those with zero exposure. 
Table A2. Time spent in the labor force.

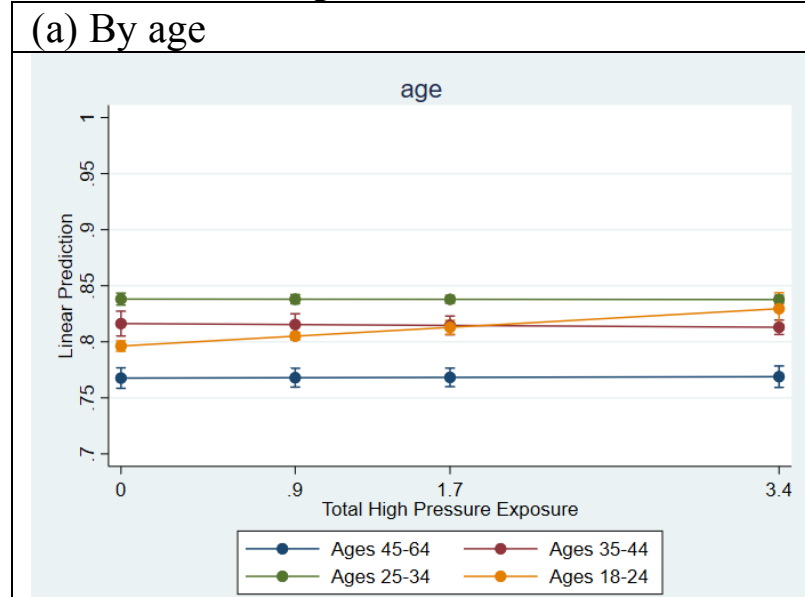

Time spent in the labor force by 18-24 yearolds with at least median high-pressure exposure is significantly higher than the same group with zero exposure.

(c) By race

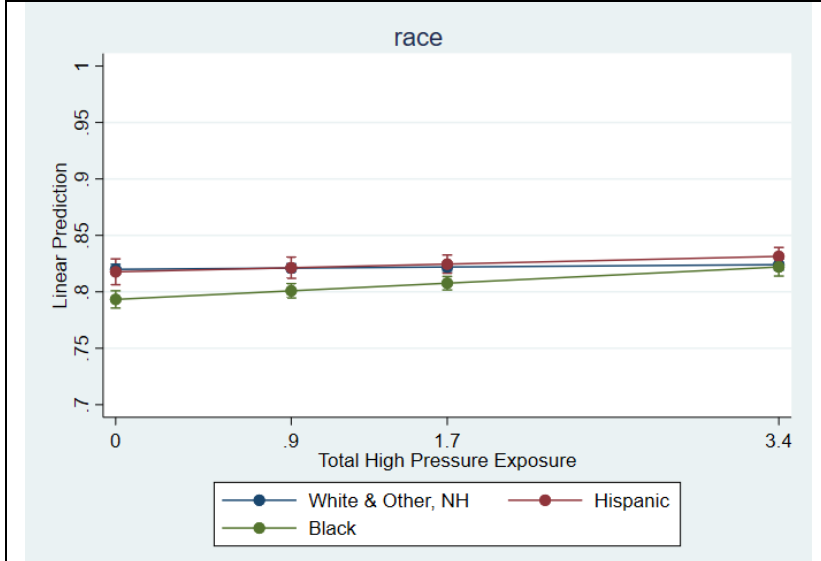

Time spent in the labor force by blacks with total high-pressure exposure at least at the 75th percentile is significantly higher than the same group with zero exposure. (b) By education

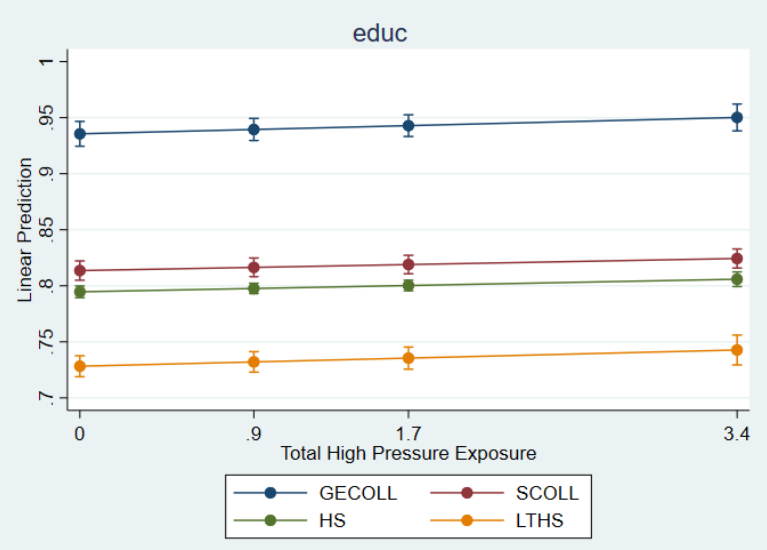

High-pressure exposure would have to be greater than at the 75th percentile for its effect on time spent in the labor force by education group to be significantly different from zero exposure.

\section{(d) By sex}

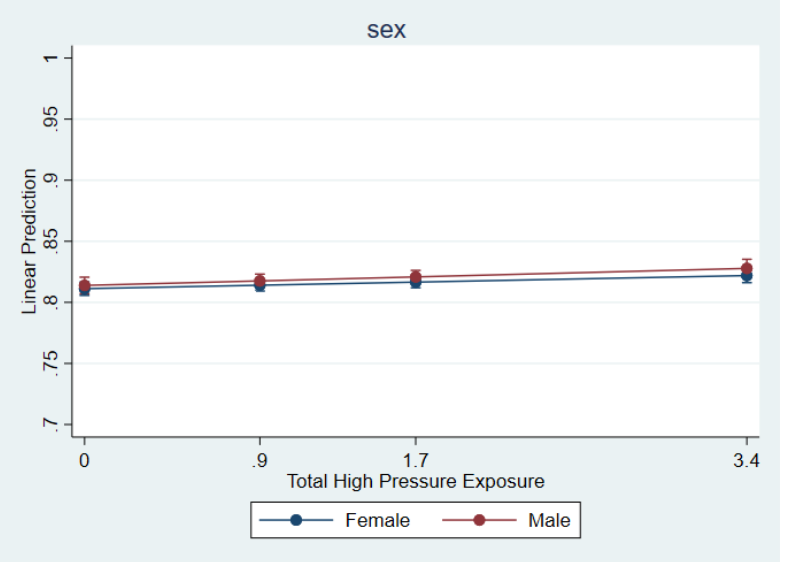

High-pressure exposure would have to be greater than at the 75 th percentile for its effect on time spent in the labor force by sex to be significantly different from zero exposure. 
Table A3. Log real hourly pay.

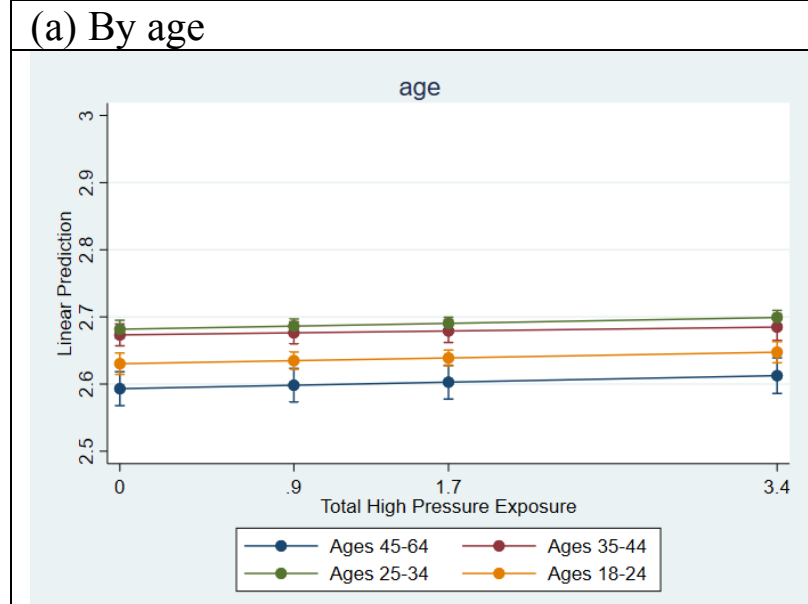

High-pressure exposure would have to be greater than at the 75th percentile for its effect on hourly pay by age to be significantly different from zero exposure.

(c) By race

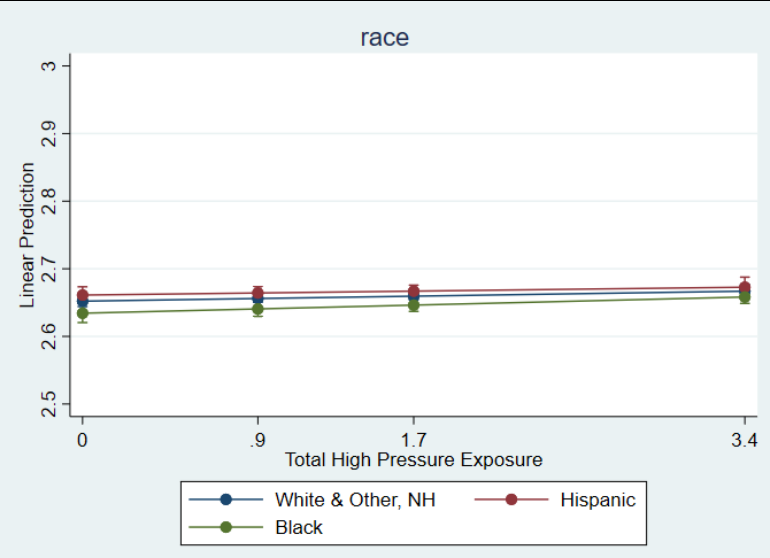

High-pressure exposure would have to be greater than at the 75th percentile for its effect on hourly pay by race to be significantly different from zero exposure. (b) By education

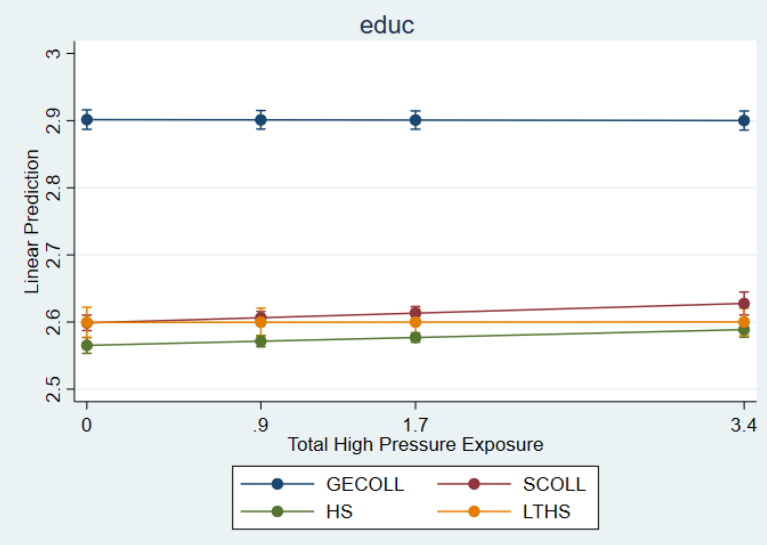

High-pressure exposure would have to be greater than at the 75th percentile for its effect on education to be significantly different from zero exposure.

(d) By sex

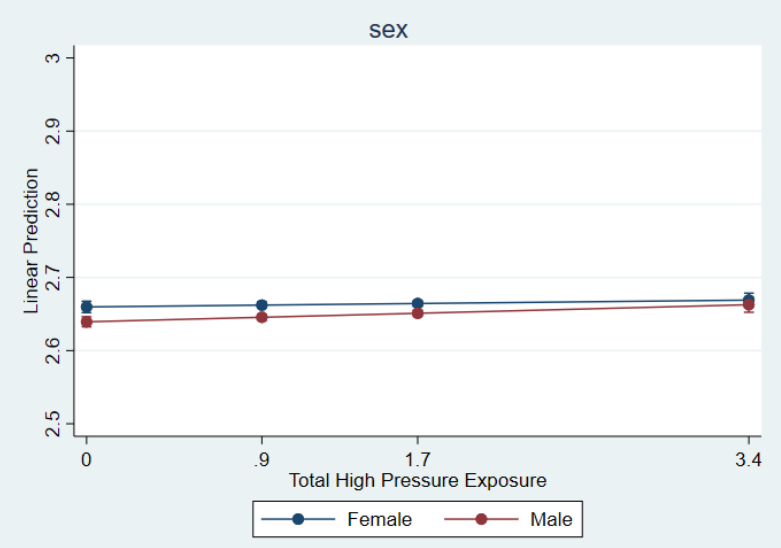

High-pressure exposure would have to be greater than at the 75 th percentile (at least the median) for its effect on hourly pay for women (men) to be significantly different from zero exposure. 
Table A4. Weekly hours.

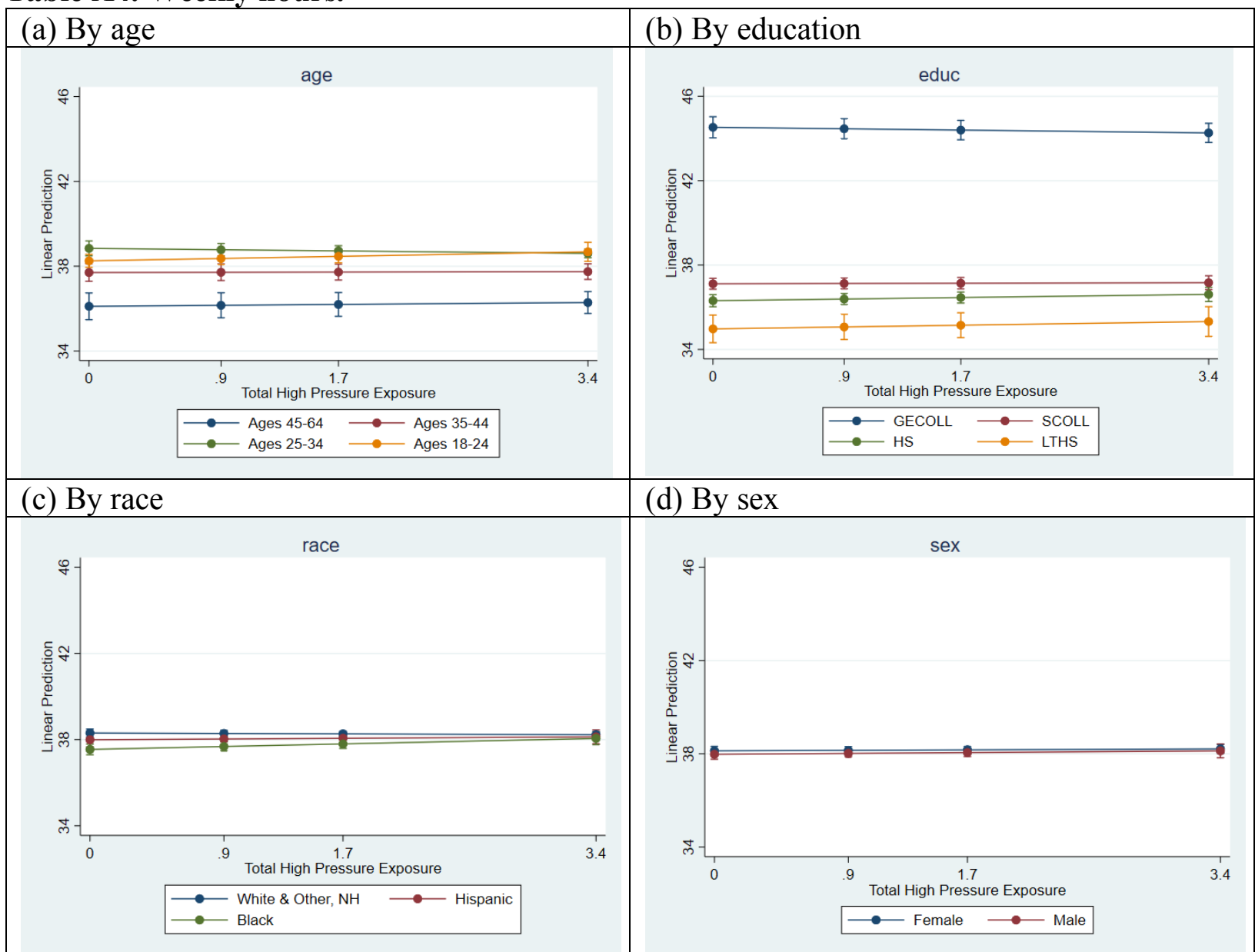

High-pressure exposure would have to be greater than at the 75th percentile for its effect on hourly pay for any group to be significantly different from zero exposure. 


\section{Appendix B. Intensity and Duration Effects for all Outcomes During High-unemployment Periods.}

Table B1. Marginal effect of high-unemployment periods and high-pressure intensity and highpressure duration on share of time unemployed and share of time in the labor force, by demographic groups.

\begin{tabular}{|c|c|c|c|c|c|c|}
\hline & \multicolumn{3}{|c|}{ Share of time spent unemployed } & \multicolumn{3}{|c|}{ Share of time in labor force } \\
\hline & $\begin{array}{l}\text { Marginal } \\
\text { effect of high } \\
\text { unempl. } \\
\frac{\partial u \text { share }}{\partial H U}\end{array}$ & $\begin{array}{c}\text { Marginal } \\
\text { effect of } \\
\text { average HP } \\
\text { intensity } \\
\left.\frac{\partial U \text { share }}{\partial H P a v g}\right|_{H U=1}\end{array}$ & $\begin{array}{c}\begin{array}{c}\text { Marginal } \\
\text { effect of } \mathrm{HP} \\
\text { duration }\end{array} \\
\left.\frac{\partial U \text { share }}{\partial H P n}\right|_{H U=1}\end{array}$ & $\begin{array}{l}\text { Marginal } \\
\text { effect of high } \\
\text { unempl. } \\
\frac{\partial L F \text { share }}{\partial H U}\end{array}$ & $\begin{array}{l}\begin{array}{c}\text { Marginal effect } \\
\text { of average HP } \\
\text { intensity }\end{array} \\
\left.\frac{\partial L F \text { share }}{\partial H P a v g}\right|_{H U=1}\end{array}$ & 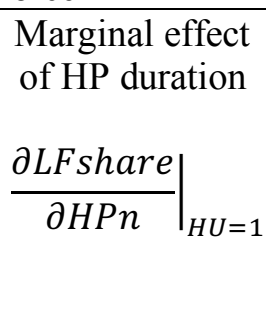 \\
\hline \multirow[t]{2}{*}{ Full Sample } & $0.0127^{* * *}$ & $-0.0097^{* * *}$ & -0.0003 & -0.0008 & $0.0130^{*}$ & 0.0019 \\
\hline & {$[0.0025]$} & {$[0.0034]$} & {$[0.0007]$} & {$[0.0049]$} & {$[0.0054]$} & {$[0.0011]$} \\
\hline \multirow[t]{2}{*}{ Ages 45-57 } & $-0.0199^{*}$ & -0.0105 & 0.0012 & -0.0001 & $0.0227^{*}$ & -0.0039 \\
\hline & {$[0.0086]$} & [0.0109] & {$[0.0019]$} & {$[0.0091]$} & {$[0.0104]$} & {$[0.0021]$} \\
\hline \multirow[t]{2}{*}{ Ages 35-44 } & 0.0033 & -0.0025 & -0.0006 & 0.0078 & -0.0077 & -0.0005 \\
\hline & {$[0.0046]$} & {$[0.0062]$} & {$[0.0012]$} & {$[0.0071]$} & {$[0.0083]$} & {$[0.0016]$} \\
\hline \multirow[t]{2}{*}{ Ages 25-34 } & $0.0140^{* * * *}$ & 0.0011 & -0.0008 & $0.0102^{*}$ & -0.0099 & 0.0025 \\
\hline & {$[0.0026]$} & {$[0.0049]$} & {$[0.0013]$} & {$[0.0052]$} & {$[0.0069]$} & {$[0.0019]$} \\
\hline \multirow[t]{2}{*}{ Ages 18-24 } & $0.0184^{* * *}$ & $-0.0322^{* * *}$ & -0.0008 & -0.0052 & $0.0510^{* * * *}$ & $0.0058^{*}$ \\
\hline & {$[0.0038]$} & {$[0.0092]$} & {$[0.0016]$} & {$[0.0061]$} & {$[0.0141]$} & {$[0.0024]$} \\
\hline \multirow[t]{2}{*}{ White, NH } & $0.0070^{*}$ & -0.0094 & 0.0017 & 0.0053 & 0.0114 & 0.0007 \\
\hline & {$[0.0030]$} & {$[0.0057]$} & {$[0.0012]$} & {$[0.0049]$} & {$[0.0089]$} & {$[0.0018]$} \\
\hline \multirow[t]{2}{*}{ Hispanic } & -0.0004 & $-0.0233^{* * *}$ & 0.0029 & 0.0041 & $0.0280^{*}$ & 0.0009 \\
\hline & {$[0.0027]$} & {$[0.0062]$} & {$[0.0012]$} & {$[0.0074]$} & {$[0.0121]$} & {$[0.0020]$} \\
\hline \multirow[t]{2}{*}{ Black, NH } & $0.0349^{* * *}$ & -0.0141 & $-0.0081^{* * * *}$ & $-0.0179^{* *}$ & $0.0206^{*}$ & $0.0085^{* * *}$ \\
\hline & {$[0.0042]$} & {$[0.0073]$} & {$[0.0017]$} & {$[0.0058]$} & {$[0.0091]$} & {$[0.0018]$} \\
\hline \multirow[t]{2}{*}{ GE College } & $-0.0077^{*}$ & $-0.0189^{* * * *}$ & $0.0032^{* *}$ & 0.0014 & $0.0266^{*}$ & 0.0025 \\
\hline & {$[0.0030]$} & {$[0.0056]$} & {$[0.0010]$} & [0.0069] & {$[0.0124]$} & {$[0.0022]$} \\
\hline \multirow[t]{2}{*}{ Some Coll } & 0.0042 & $-0.01444^{* * *}$ & $0.0034^{* * * *}$ & -0.0064 & $0.0287^{* * *}$ & -0.0003 \\
\hline & {$[0.0032]$} & {$[0.0046]$} & {$[0.0010]$} & {$[0.0055]$} & {$[0.0099]$} & {$[0.0019]$} \\
\hline \multirow[t]{2}{*}{ High Schl } & $0.0141^{* * *}$ & $-0.0127^{*}$ & -0.0014 & 0.0056 & 0.0124 & 0.0032 \\
\hline & {$[0.0024]$} & {$[0.0054]$} & {$[0.0009]$} & {$[0.0055]$} & {$[0.0088]$} & {$[0.0017]$} \\
\hline \multirow[t]{2}{*}{ LT HS } & $0.0406^{* * *}$ & -0.0065 & $-0.0091^{* * *}$ & -0.0073 & -0.0006 & $0.0065^{* *}$ \\
\hline & {$[0.0050]$} & {$[0.0123]$} & {$[0.0028]$} & {$[0.0070]$} & {$[0.0109]$} & {$[0.0025]$} \\
\hline \multirow[t]{2}{*}{ Females } & $0.0133^{* * *}$ & -0.0045 & $-0.0031^{*}$ & -0.0014 & -0.0137 & $0.0074^{* * *}$ \\
\hline & {$[0.0029]$} & {$[0.0065]$} & {$[0.0012]$} & {$[0.0049]$} & {$[0.0105]$} & {$[0.0020]$} \\
\hline \multirow[t]{2}{*}{ Males } & $0.0121^{* * * *}$ & $-0.0214^{* * *}$ & 0.0017 & -0.0003 & $0.0471^{* * *}$ & -0.0018 \\
\hline & {$[0.0028]$} & {$[0.0049]$} & {$[0.0010]$} & {$[0.0060]$} & {$[0.0082]$} & {$[0.0016]$} \\
\hline Obs & 253,186 & & & 272,186 & & \\
\hline
\end{tabular}

Notes: Data source is the National Longitudinal Survey of Youth (1979 and 1997). Robust standard errors, in brackets, are clustered at the state level; $* * * \mathrm{p}<0.01, * * \mathrm{p}<0.05, * \mathrm{p}<0.1$. All regressions include year, state, and individual fixed effects. Regressions include the NLSY oversample of the poor and racial/ethnic minorities. Sample is restricted to individual who had nonzero employment during expansionary periods. Statistically significant moderation of the impact of high unemployment periods from high-pressure exposure are indicated in bold. 
Table B2. Marginal effect of high-unemployment periods and high-pressure intensity and highpressure duration on log real hourly pay and weekly hours, by demographic group.

\begin{tabular}{|c|c|c|c|c|c|c|}
\hline & \multicolumn{3}{|c|}{ Log Real Hourly Pay } & \multicolumn{3}{|c|}{ Weekly Hours } \\
\hline & $\begin{array}{l}\text { Marginal } \\
\text { effect of } \\
\text { high } \\
\text { unempl. } \\
\frac{\partial \ln W}{\partial H U}\end{array}$ & $\begin{array}{l}\text { Marginal effect } \\
\text { of average HP } \\
\text { intensity } \\
\left.\frac{\partial \ln W}{\partial H P a v g}\right|_{H U=1}\end{array}$ & $\begin{array}{l}\text { Marginal } \\
\text { effect of HP } \\
\text { duration } \\
\left.\frac{\partial \ln W}{\partial H P n}\right|_{H U=1}\end{array}$ & $\begin{array}{l}\text { Marginal } \\
\text { effect of } \\
\text { high } \\
\text { unempl. } \\
\frac{\partial H r s}{\partial H U}\end{array}$ & $\begin{array}{l}\text { Marginal effect } \\
\text { of average HP } \\
\text { intensity } \\
\left.\frac{\partial H r s}{\partial H P a v g}\right|_{H U=1}\end{array}$ & $\begin{array}{l}\begin{array}{c}\text { Marginal } \\
\text { effect of HP } \\
\text { duration }\end{array} \\
\left.\frac{\partial H r s}{\partial H P n}\right|_{H U=1}\end{array}$ \\
\hline Full Sample & $-0.0269^{* * *}$ & $0.0262^{* *}$ & 0.001 & $-0.4290^{* * *}$ & 0.0397 & $0.1078^{* *}$ \\
\hline & {$[0.0039]$} & {$[0.0088]$} & {$[0.0012]$} & {$[0.1202]$} & {$[0.2164]$} & {$[0.0334]$} \\
\hline Ages 45-57 & $-0.0468^{* * *}$ & 0.0168 & 0.0048 & -0.3338 & -0.6405 & 0.1087 \\
\hline & {$[0.0117]$} & {$[0.0194]$} & {$[0.0034]$} & {$[0.3888]$} & {$[0.3370]$} & {$[0.0683]$} \\
\hline Ages $35-44$ & $-0.0292^{* * *}$ & $0.0268^{*}$ & 0.0013 & $-0.7030^{* * *}$ & $-1.0887^{* *}$ & $0.3065^{* * *}$ \\
\hline & {$[0.0059]$} & {$[0.0113]$} & {$[0.0024]$} & {$[0.2039]$} & {$[0.3380]$} & {$[0.0594]$} \\
\hline Ages 25-34 & $-0.0219^{* *}$ & $0.0453^{* *}$ & -0.0009 & -0.5125 & 0.0643 & -0.0065 \\
\hline & {$[0.0084]$} & {$[0.0160]$} & {$[0.0030]$} & {$[0.2714]$} & {$[0.3911]$} & {$[0.0688]$} \\
\hline Ages 18-24 & $-0.0216^{* * * *}$ & 0.0444 & 0.002 & -0.0464 & 0.8734 & $0.2952^{* *}$ \\
\hline & {$[0.0046]$} & {$[0.0264]$} & {$[0.0029]$} & {$[0.1163]$} & {$[0.6782]$} & {$[0.0988]$} \\
\hline White, NH & $-0.0251^{* * *}$ & $0.0384^{* *}$ & 0.0013 & -0.2375 & -0.0275 & $0.1233^{*}$ \\
\hline & {$[0.0044]$} & {$[0.0148]$} & {$[0.0021]$} & {$[0.1403]$} & {$[0.3612]$} & {$[0.0598]$} \\
\hline Hispanic & $-0.0165^{* *}$ & 0.0147 & 0.0039 & $-0.4668^{* *}$ & -0.4909 & $0.3239^{* * * *}$ \\
\hline & {$[0.0056]$} & {$[0.0155]$} & {$[0.0028]$} & {$[0.1719]$} & {$[0.3453]$} & {$[0.0787]$} \\
\hline Black, NH & $-0.0375^{* * *}$ & $0.0536^{* * *}$ & -0.0006 & $-0.7856^{* * *}$ & 0.6474 & $0.1842^{*}$ \\
\hline & {$[0.0077]$} & {$[0.0163]$} & {$[0.0023]$} & {$[0.1501]$} & {$[0.4397]$} & {$[0.0907]$} \\
\hline GE College & 0.0134 & 0.0323 & -0.0027 & $0.6457^{*}$ & -0.361 & 0.1084 \\
\hline & {$[0.0092]$} & {$[0.0206]$} & {$[0.0043]$} & {$[0.2611]$} & {$[0.5625]$} & {$[0.1164]$} \\
\hline Some Coll & $-0.0348^{* * * *}$ & $0.0476^{\star * *}$ & $0.0051^{*}$ & $-0.5513^{* *}$ & 0.8344 & 0.0784 \\
\hline & {$[0.0072]$} & {$[0.0184]$} & {$[0.0022]$} & {$[0.1801]$} & {$[0.5093]$} & {$[0.0847]$} \\
\hline High Schl & $-0.0433^{* * *}$ & $0.0357^{* *}$ & $0^{0.0038}{ }^{*}$ & $-0.8976^{* * *}$ & -0.3321 & $0.2920^{* * *}$ \\
\hline & {$[0.0060]$} & {$[0.0134]$} & {$[0.0019]$} & {$[0.1665]$} & {$[0.3268]$} & {$[0.0646]$} \\
\hline LT HS & $-0.0280^{* *}$ & 0.03 & -0.0061 & $-0.5473^{* *}$ & -0.045 & 0.2179 \\
\hline & {$[0.0090]$} & {$[0.0208]$} & {$[0.0032]$} & {$[0.1678]$} & {$[0.6793]$} & {$[0.1206]$} \\
\hline Females & $-0.0174^{* * *}$ & 0.0216 & 0.0015 & $-0.2511^{*}$ & -0.4899 & $0.2471^{* * *}$ \\
\hline & {$[0.0044]$} & {$[0.0152]$} & {$[0.0021]$} & {$[0.1203]$} & {$[0.2807]$} & {$[0.0556]$} \\
\hline Males & $-0.0359^{* * *}$ & $0.05300^{* * * *}$ & 0.0011 & $-0.5975^{* * *}$ & 0.5702 & 0.1133 \\
\hline & {$[0.0040]$} & {$[0.0145]$} & {$[0.0021]$} & {$[0.1716]$} & {$[0.5118]$} & {$[0.0681]$} \\
\hline Obs & 146,556 & & & 155,015 & & \\
\hline
\end{tabular}

Notes: Data source is the National Longitudinal Survey of Youth (1979 and 1997). Robust standard errors, in brackets, are clustered at the state level; ${ }^{* * *} \mathrm{p}<0.01, * * \mathrm{p}<0.05, * \mathrm{p}<0.1$. All regressions include year, state, and individual fixed effects as well as controls for industry and occupation. Regressions include the NLSY oversample of the poor and racial/ethnic minorities. Sample is restricted to individual who had nonzero employment during expansionary periods. Only workers with non-zero wages and hours are included in analysis. Statistically significant moderation of the impact of high unemployment periods from high-pressure exposure are indicated in bold. 


\section{Appendix C. Supplemental Tables for Additional Analyses Discussed in the Text}

Table C1. Marginal effect of the impact of low-unemployment periods and total high-pressure exposure on labor market outcomes, by demographic groups.

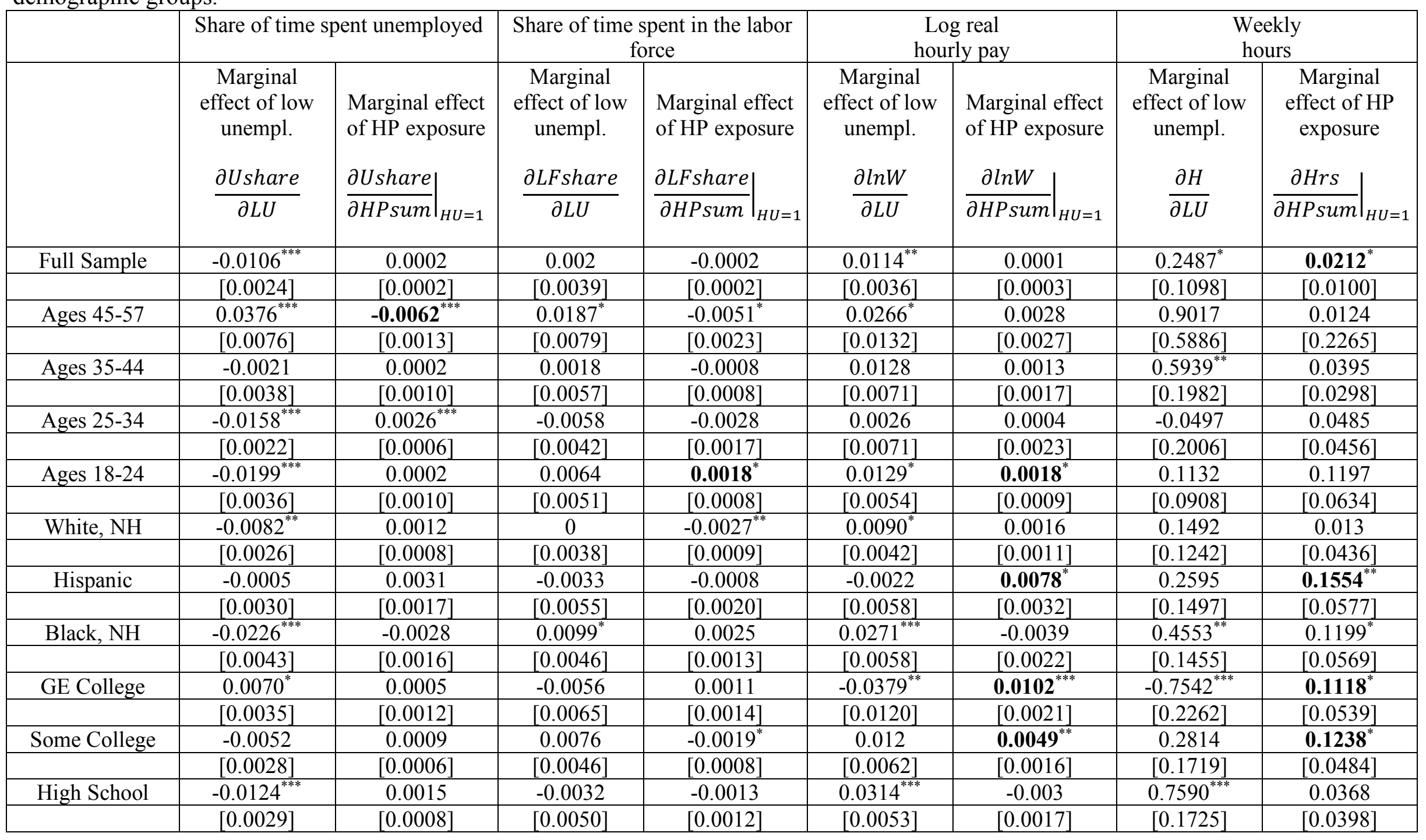




\begin{tabular}{|c|c|c|c|c|c|c|c|c|}
\hline & \multicolumn{2}{|c|}{ Share of time spent unemployed } & \multicolumn{2}{|c|}{$\begin{array}{c}\text { Share of time spent in the labor } \\
\text { force }\end{array}$} & \multicolumn{2}{|c|}{$\begin{array}{c}\text { Log real } \\
\text { hourly pay }\end{array}$} & \multicolumn{2}{|c|}{$\begin{array}{l}\text { Weekly } \\
\text { hours }\end{array}$} \\
\hline & $\begin{array}{c}\text { Marginal } \\
\text { effect of low } \\
\text { unempl. } \\
\text { dUshare } \\
\end{array}$ & $\begin{array}{l}\text { Marginal effect } \\
\text { of HP exposure } \\
\text { oUshare }\end{array}$ & $\begin{array}{c}\text { Marginal } \\
\text { effect of low } \\
\text { unempl. } \\
\text { dLFshare } \\
\end{array}$ & $\begin{array}{l}\text { Marginal effect } \\
\text { of HP exposure } \\
\text { oLFshare }\end{array}$ & $\begin{array}{c}\text { Marginal } \\
\text { effect of low } \\
\text { unempl. } \\
\\
\partial \ln W\end{array}$ & $\begin{array}{l}\text { Marginal effect } \\
\text { of HP exposure } \\
\partial \ln W \\
\end{array}$ & $\begin{array}{l}\text { Marginal } \\
\text { effect of low } \\
\text { unempl. } \\
\partial H \\
\end{array}$ & $\begin{array}{c}\text { Marginal } \\
\text { effect of HP } \\
\text { exposure } \\
\text { oHrs }\end{array}$ \\
\hline & $\partial L U$ & $\left.\overline{\partial H P s u m}\right|_{H U=1}$ & $\partial L U$ & $\left.\overline{\partial H P s u m}\right|_{H U=1}$ & $\partial L U$ & $\left.\overline{\partial H P s u m}\right|_{H U=1}$ & $\overline{\partial L U}$ & $\left.\overline{\partial H P s u m}\right|_{H U=1}$ \\
\hline \multirow[t]{2}{*}{ LT High School } & $-0.0331^{* * *}$ & -0.0018 & 0.0107 & -0.0012 & $0.0310^{* * *}$ & $-0.0077^{*}$ & $0.4238^{* *}$ & -0.0276 \\
\hline & {$[0.0046]$} & {$[0.0012]$} & {$[0.0059]$} & {$[0.0011]$} & {$[0.0080]$} & {$[0.0035]$} & {$[0.1543]$} & {$[0.0673]$} \\
\hline \multirow[t]{2}{*}{ Females } & $-0.0101^{* * *}$ & -0.0002 & 0.0047 & -0.0016 & 0.0079 & -0.0014 & 0.2281 & 0.0292 \\
\hline & {$[0.0029]$} & {$[0.0005]$} & {$[0.0041]$} & {$[0.0010]$} & {$[0.0043]$} & {$[0.0017]$} & {$[0.1471]$} & {$[0.0464]$} \\
\hline \multirow[t]{2}{*}{ Males } & $-0.0111^{* * *}$ & 0.0012 & -0.0007 & -0.0004 & $0.0147^{* * * *}$ & $0.0041^{* * * *}$ & 0.2683 & 0.105 \\
\hline & {$[0.0027]$} & {$[0.0008]$} & {$[0.0046]$} & {$[0.0010]$} & {$[0.0041]$} & {$[0.0009]$} & {$[0.1594]$} & {$[0.0818]$} \\
\hline Observations & 253,186 & & 272,186 & & 146,556 & & 155,015 & \\
\hline
\end{tabular}

Notes: Data source is the National Longitudinal Survey of Youth (1979 and 1997). Robust standard errors, in brackets, are clustered at the state level; *** $\mathrm{p}<0.01, * * \mathrm{p}<0.05, * \mathrm{p}<0.1$. All regressions include year, state, and individual fixed effects. Hourly pay and weekly hours regressions include controls for occupation and industry. Regressions include the NLSY oversample of the poor and racial/ethnic minorities. Sample is restricted to individual who had nonzero employment during expansionary periods, positive wage (for log real hourly pay analysis), and positive hours (for weekly hours analysis).

Statistically significant moderation of the impact of high unemployment periods from high-pressure exposure are indicated in bold. 
Table C2. Marginal impact of recessions and total high-pressure exposure on labor market outcomes, by demographic groups.

\begin{tabular}{|c|c|c|c|c|c|c|c|c|}
\hline & \multicolumn{2}{|c|}{ Share of time spent unemployed } & \multicolumn{2}{|c|}{$\begin{array}{c}\text { Share of time spent in the labor } \\
\text { force }\end{array}$} & \multicolumn{2}{|c|}{$\begin{array}{c}\text { Log real } \\
\text { hourly pay }\end{array}$} & \multicolumn{2}{|c|}{$\begin{array}{l}\text { Weekly } \\
\text { hours }\end{array}$} \\
\hline & $\begin{array}{c}\text { Marginal } \\
\text { effect of } \\
\text { recessions } \\
\frac{\partial U \text { share }}{\partial \operatorname{Rec}}\end{array}$ & $\begin{array}{l}\text { Marginal effect } \\
\text { of HP exposure } \\
\left.\frac{\partial U \text { share }}{\partial H P \text { sum }}\right|_{\text {Rec }=1}\end{array}$ & $\begin{array}{l}\begin{array}{c}\text { Marginal } \\
\text { effect of } \\
\text { recessions }\end{array} \\
\frac{\partial L F \text { share }}{\partial R e c}\end{array}$ & 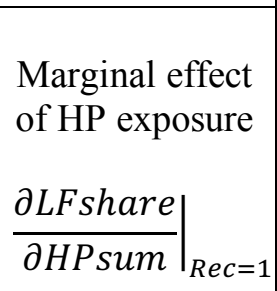 & $\begin{array}{c}\begin{array}{c}\text { Marginal } \\
\text { effect of } \\
\text { recessions }\end{array} \\
\frac{\partial \ln W}{\partial \operatorname{Rec}}\end{array}$ & $\begin{array}{l}\text { Marginal effect } \\
\text { of HP exposure } \\
\left.\frac{\partial \ln W}{\partial H P \text { sum }}\right|_{\text {Rec=1 }}\end{array}$ & $\begin{array}{c}\begin{array}{c}\text { Marginal } \\
\text { effect of } \\
\text { recessions }\end{array} \\
\frac{\partial H r s}{\partial \operatorname{Rec}}\end{array}$ & $\begin{array}{c}\text { Marginal } \\
\text { effect of HP } \\
\text { exposure } \\
\left.\frac{\partial H r s}{\partial H P s u m}\right|_{\text {Rec=1 }}\end{array}$ \\
\hline \multirow[t]{2}{*}{ Full Sample } & $0.0375^{* * *}$ & $-0.0009^{* * *}$ & $-0.0366^{* * *}$ & $0.0014^{* * *}$ & $-0.1561^{* * *}$ & $0.0016{ }^{* * *}$ & $-4.0546^{* * *}$ & 0.0016 \\
\hline & {$[0.0052]$} & {$[0.0002]$} & {$[0.0072]$} & {$[0.0004]$} & {$[0.0193]$} & {$[0.0003]$} & {$[0.7106]$} & {$[0.0078]$} \\
\hline \multirow[t]{2}{*}{ Ages 45-57 } & $0.0619^{* * *}$ & $-0.0029^{*}$ & $-0.0539^{* * *}$ & -0.001 & $-0.1686^{* * *}$ & $0.0063^{* *}$ & $-3.8885^{* * *}$ & -0.0942 \\
\hline & {$[0.0085]$} & {$[0.0014]$} & {$[0.0070]$} & {$[0.0031]$} & {$[0.0185]$} & [0.0024] & {$[0.6570]$} & {$[0.1048]$} \\
\hline \multirow{2}{*}{ Ages 35-44 } & $0.0508^{* * *}$ & -0.0036 & $-0.0609^{* * *}$ & -0.0038 & $-0.2080^{* * *}$ & 0.0061 & $-5.9567^{* * *}$ & 0.133 \\
\hline & {$[0.0085]$} & {$[0.0042]$} & {$[0.0111]$} & {$[0.0048]$} & {$[0.0249]$} & {$[0.0047]$} & {$[0.8296]$} & {$[0.1816]$} \\
\hline \multirow[t]{2}{*}{ Ages 25-34 } & $0.0341^{* * * *}$ & -0.0012 & $-0.0373^{* * *}$ & -0.0002 & $-0.1709^{* * *}$ & $0.0114^{* *}$ & $-4.0444^{* * * *}$ & $-0.1840^{* *}$ \\
\hline & {$[0.0064]$} & {$[0.0008]$} & {$[0.0082]$} & {$[0.0010]$} & {$[0.0186]$} & {$[0.0037]$} & {$[0.6783]$} & {$[0.0660]$} \\
\hline \multirow[t]{2}{*}{ Ages 18-24 } & $0.0302^{* * * *}$ & $-0.0065^{* *}$ & $-0.0237^{* * *}$ & $0.0144^{* * *}$ & $-0.1135^{* * *}$ & $0.0077^{* *}$ & $-3.1780^{* * *}$ & $0.2069^{* * * *}$ \\
\hline & {$[0.0047]$} & {$[0.0022]$} & {$[0.0071]$} & {$[0.0037]$} & {$[0.0201]$} & {$[0.0028]$} & {$[0.7675]$} & {$[0.0625]$} \\
\hline \multirow[t]{2}{*}{ White, NH } & $0.0304^{* * * *}$ & $-0.0024^{* *}$ & $-0.0281^{* * *}$ & 0.0025 & $-0.1560^{* * *}$ & $0.0071^{* * * *}$ & $-3.8776^{* * * *}$ & 0.0391 \\
\hline & {$[0.0050]$} & {$[0.0008]$} & {$[0.0073]$} & {$[0.0017]$} & {$[0.0189]$} & {$[0.0018]$} & {$[0.7192]$} & {$[0.0485]$} \\
\hline \multirow{2}{*}{ Hispanic } & $0.0384^{* * * *}$ & $-0.0039^{* *}$ & $-0.0396^{* * *}$ & $0.0058^{* * *}$ & $-0.1513^{* * *}$ & 0.0061 & $-4.0198^{* * *}$ & -0.1197 \\
\hline & {$[0.0054]$} & {$[0.0014]$} & {$[0.0077]$} & {$[0.0018]$} & {$[0.0231]$} & {$[0.0037]$} & [0.7199] & {$[0.1449]$} \\
\hline \multirow[t]{2}{*}{ Black, NH } & $0.0520^{* * *}$ & $-0.0063^{* *}$ & $-0.0525^{* * *}$ & $0.0093^{* * * *}$ & $-0.1598^{* * *}$ & $0.0127^{* * *}$ & $-4.4493^{* * * *}$ & 0.1258 \\
\hline & {$[0.0069]$} & {$[0.0023]$} & {$[0.0094]$} & {$[0.0022]$} & {$[0.0195]$} & {$[0.0035]$} & {$[0.7549]$} & {$[0.0750]$} \\
\hline \multirow[t]{2}{*}{ GE College } & $0.0327^{* * *}$ & -0.0003 & $-0.0367^{* * * *}$ & $0.0052^{*}$ & $-0.1298^{* * *}$ & -0.0025 & $-2.9590^{* * * *}$ & -0.2061 \\
\hline & {$[0.0061]$} & {$[0.0011]$} & {$[0.0086]$} & {$[0.0026]$} & {$[0.0220]$} & {$[0.0045]$} & {$[0.7153]$} & {$[0.1196]$} \\
\hline \multirow[t]{2}{*}{ Some College } & $0.0303^{* * *}$ & 0.0004 & $-0.0313^{* * *}$ & 0.0006 & $-0.1598^{* * *}$ & $0.0060^{*}$ & $-3.8884^{* * *}$ & $-0.1583^{*}$ \\
\hline & {$[0.0052]$} & {$[0.0008]$} & {$[0.0078]$} & {$[0.0018]$} & {$[0.0186]$} & {$[0.0025]$} & {$[0.7765]$} & {$[0.0730]$} \\
\hline \multirow[t]{2}{*}{ High School } & $0.0367^{* * *}$ & $-0.0053^{* * *}$ & $-0.0342^{* * *}$ & $0.0060^{* * *}$ & $-0.1669^{* * *}$ & $0.0135^{* * *}$ & $-4.6127^{* * *}$ & $0.2278^{* *}$ \\
\hline & {$[0.0057]$} & {$[0.0010]$} & {$[0.0078]$} & {$[0.0017]$} & {$[0.0195]$} & {$[0.0029]$} & {$[0.7111]$} & {$[0.0881]$} \\
\hline \multirow[t]{2}{*}{ LT High School } & $0.0543^{* * *}$ & $-0.0101^{* * *}$ & $-0.0483^{* * *}$ & $0.0084^{* * *}$ & $-0.1600^{* * *}$ & $0.0161^{* * *}$ & $-4.6124^{* * *}$ & $0.2860^{* *}$ \\
\hline & {$[0.0055]$} & {$[0.0026]$} & {$[0.0078]$} & {$[0.0024]$} & {$[0.0205]$} & {$[0.0041]$} & {$[0.6874]$} & {$[0.1077]$} \\
\hline Females & $0.0415^{* * *}$ & $-0.0041^{* *}$ & $-0.0331^{* * *}$ & 0.0023 & $-0.1525^{* * *}$ & $0.0071^{* * *}$ & $-3.9138^{* * * *}$ & 0.0828 \\
\hline
\end{tabular}




\begin{tabular}{|c|c|c|c|c|c|c|c|c|}
\hline & \multicolumn{2}{|c|}{ Share of time spent unemployed } & \multicolumn{2}{|c|}{$\begin{array}{l}\text { Share of time spent in the labor } \\
\text { force }\end{array}$} & \multicolumn{2}{|c|}{$\begin{array}{l}\text { Log real } \\
\text { hourly pay }\end{array}$} & \multicolumn{2}{|c|}{$\begin{array}{l}\text { Weekly } \\
\text { hours }\end{array}$} \\
\hline & $\begin{array}{l}\text { Marginal } \\
\text { effect of } \\
\text { recessions } \\
\text { oUshare }\end{array}$ & $\begin{array}{l}\text { Marginal effect } \\
\text { of HP exposure } \\
\text { oUshare }\end{array}$ & $\begin{array}{l}\text { Marginal } \\
\text { effect of } \\
\text { recessions } \\
\text { dLFshare }\end{array}$ & $\begin{array}{l}\text { Marginal effect } \\
\text { of HP exposure } \\
\text { oLFshare }\end{array}$ & $\begin{array}{c}\text { Marginal } \\
\text { effect of } \\
\text { recessions } \\
\partial \ln W\end{array}$ & $\begin{array}{l}\text { Marginal effect } \\
\text { of HP exposure } \\
\quad \partial \ln W\end{array}$ & $\begin{array}{c}\text { Marginal } \\
\text { effect of } \\
\text { recessions } \\
\text { дHrs }\end{array}$ & $\begin{array}{l}\text { Marginal } \\
\text { effect of HP } \\
\text { exposure } \\
\text { əHrs }\end{array}$ \\
\hline & $\partial R e c$ & $\left.\overline{\partial H P s u m}\right|_{\text {Rec }=1}$ & $\partial R e c$ & $\left.\overline{\partial H P s u m}\right|_{\text {Rec }=1}$ & $\overline{\partial R e c}$ & $\left.\overline{\partial H P s u m}\right|_{R e c=1}$ & $\overline{\partial R e c}$ & $\left.\overline{\partial H P s u m}\right|_{\text {Rec }=1}$ \\
\hline & {$[0.0062]$} & {$[0.0013]$} & {$[0.0076]$} & {$[0.0016]$} & {$[0.0191]$} & {$[0.0020]$} & {$[0.7281]$} & {$[0.0678]$} \\
\hline Males & $0.0337^{* * *}$ & $-0.0033^{* * *}$ & $-0.0402^{* * *}$ & $0.0074^{* * *}$ & $-0.1596^{* * *}$ & $0.0095^{* * *}$ & $-4.1864^{* * *}$ & -0.0178 \\
\hline & {$[0.0049]$} & {$[0.0009]$} & {$[0.0074]$} & {$[0.0019]$} & {$[0.0199]$} & {$[0.0023]$} & {$[0.7167]$} & {$[0.0652]$} \\
\hline Observations & 253,186 & & 272,186 & & 146,556 & & 155,015 & \\
\hline
\end{tabular}

Notes: Data source is the National Longitudinal Survey of Youth (1979 and 1997). Robust standard errors, in brackets, are clustered at the state level; *** $\mathrm{p}<0.01, * * \mathrm{p}<0.05, * \mathrm{p}<0.1$. All regressions include year, state, and individual fixed effects. Hourly pay and weekly hours regressions include controls for occupation and industry. Regressions include the NLSY oversample of the poor and racial/ethnic minorities. Sample is restricted to individual who had nonzero employment during expansionary periods, positive wage (for log real hourly pay analysis), and positive hours (for weekly hours analysis).

Statistically significant moderation of the impact of high unemployment periods from high-pressure exposure are indicated in bold. 
Table C3. Marginal effect of the impact of high-unemployment periods and total high-pressure exposure on labor market outcomes, by demographic groups, excluding individual fixed effects.

\begin{tabular}{|c|c|c|c|c|c|c|c|c|}
\hline & Share of time & ent unemployed & Share of time & $\begin{array}{l}\text { pent in the labor } \\
\text { rce }\end{array}$ & & $\begin{array}{l}\text { real } \\
\text { y pay }\end{array}$ & & $\begin{array}{l}\text { ekly } \\
\text { urs }\end{array}$ \\
\hline & $\begin{array}{c}\begin{array}{c}\text { Marginal } \\
\text { effect of } \\
\text { high unempl. }\end{array} \\
\frac{\partial U \text { share }}{\partial H U}\end{array}$ & $\begin{array}{l}\text { Marginal effect } \\
\text { of HP exposure } \\
\left.\frac{\partial U \text { share }}{\partial H P \text { sum }}\right|_{H U=1}\end{array}$ & $\begin{array}{c}\begin{array}{c}\text { Marginal } \\
\text { effect of } \\
\text { high unempl. }\end{array} \\
\frac{\partial L F \text { share }}{\partial H U}\end{array}$ & $\begin{array}{l}\text { Marginal effect } \\
\text { of HP exposure } \\
\left.\frac{\partial L F \text { share }}{\partial H P \text { sum }}\right|_{H U=1}\end{array}$ & $\begin{array}{c}\begin{array}{c}\text { Marginal } \\
\text { effect of } \\
\text { high unempl. }\end{array} \\
\frac{\partial \ln W}{\partial H U}\end{array}$ & $\begin{array}{l}\text { Marginal effect } \\
\text { of HP exposure } \\
\left.\frac{\partial \ln W}{\partial H P s u m}\right|_{H U=1}\end{array}$ & $\begin{array}{c}\begin{array}{c}\text { Marginal } \\
\text { effect of } \\
\text { high unempl. }\end{array} \\
\frac{\partial H r s}{\partial H U}\end{array}$ & $\begin{array}{l}\begin{array}{c}\text { Marginal } \\
\text { effect of } \mathrm{HP} \\
\text { exposure }\end{array} \\
\left.\frac{\partial H r s}{\partial H P s u m}\right|_{H U=1}\end{array}$ \\
\hline Full Sample & $0.0127^{* * *}$ & $-0.0016^{* * *}$ & -0.0011 & $0.0034^{* * *}$ & $-0.0247^{* * *}$ & $0.0048^{*}$ & $-0.3846^{* * *}$ & $\mathbf{0 . 0 7 1 3}^{*}$ \\
\hline & {$[0.0025]$} & {$[0.0004]$} & {$[0.0048]$} & {$[0.0008]$} & {$[0.0035]$} & {$[0.0019]$} & {$[0.1147]$} & {$[0.0337]$} \\
\hline Ages 45-57 & $-0.0211^{*}$ & -0.0008 & -0.0016 & 0.0002 & -0.0205 & $0.0034^{*}$ & -0.3839 & 0.014 \\
\hline & {$[0.0086]$} & {$[0.0012]$} & {$[0.0086]$} & {$[0.0013]$} & {$[0.0107]$} & {$[0.0017]$} & {$[0.3590]$} & {$[0.0384]$} \\
\hline Ages 35-44 & 0.0004 & $-0.0015^{*}$ & 0.0056 & -0.0005 & -0.0073 & $0.0050^{*}$ & $-0.5991^{* *}$ & 0.0443 \\
\hline & {$[0.0042]$} & {$[0.0007]$} & {$[0.0058]$} & {$[0.0012]$} & {$[0.0088]$} & {$[0.0024]$} & {$[0.2091]$} & {$[0.0443]$} \\
\hline Ages 25-34 & $0.0170^{* * *}$ & -0.0008 & 0.0051 & 0.001 & $-0.0373^{* * *}$ & $0.0084^{*}$ & -0.4992 & 0.003 \\
\hline & {$[0.0024]$} & {$[0.0007]$} & {$[0.0055]$} & {$[0.0009]$} & {$[0.0103]$} & {$[0.0039]$} & {$[0.2689]$} & {$[0.0531]$} \\
\hline Ages 18-24 & $0.0192^{* * * *}$ & $-0.0046^{* * *}$ & -0.0046 & $0.0114^{* * * *}$ & $-0.0233^{* * *}$ & $0.0079^{*}$ & -0.0834 & $0.2873^{* * *}$ \\
\hline & {$[0.0039]$} & {$[0.0012]$} & {$[0.0057]$} & {$[0.0028]$} & {$[0.0048]$} & {$[0.0037]$} & {$[0.1206]$} & {$[0.0988]$} \\
\hline White, NH & $0.0083^{* *}$ & 0.0001 & 0.0029 & $0.0026^{* *}$ & $-0.0232^{* * * *}$ & $0.0064^{*}$ & -0.2152 & 0.0601 \\
\hline & {$[0.0029]$} & {$[0.0005]$} & {$[0.0046]$} & {$[0.0010]$} & {$[0.0042]$} & {$[0.0030]$} & {$[0.1299]$} & {$[0.0515]$} \\
\hline Hispanic & 0.0006 & -0.0014 & 0.0044 & $0.0048^{* *}$ & $-0.0159^{* *}$ & 0.0066 & $-0.4528^{* * *}$ & 0.1347 \\
\hline & {$[0.0029]$} & {$[0.0009]$} & {$[0.0066]$} & {$[0.0015]$} & {$[0.0055]$} & {$[0.0036]$} & {$[0.1614]$} & {$[0.0841]$} \\
\hline Black, NH & $0.0309^{* * *}$ & $-0.0082^{* * *}$ & $-0.0134^{*}$ & $0.0091^{* * *}$ & $-0.0345^{* * * *}$ & $0.0083^{* * *}$ & $-0.6886^{* * *}$ & $0.2248^{* * *}$ \\
\hline & {$[0.0041]$} & {$[0.0011]$} & {$[0.0056]$} & {$[0.0016]$} & {$[0.0064]$} & {$[0.0022]$} & {$[0.1532]$} & {$[0.0537]$} \\
\hline GE College & $-0.0080^{* *}$ & 0.0004 & 0.0058 & $0.0043^{*}$ & 0.0127 & 0.0015 & $0.6631^{* *}$ & -0.027 \\
\hline & {$[0.0030]$} & {$[0.0005]$} & {$[0.0065]$} & {$[0.0018]$} & {$[0.0094]$} & {$[0.0017]$} & {$[0.2540]$} & {$[0.0417]$} \\
\hline Some College & 0.0047 & 0.0007 & -0.0067 & $0.0044^{* * *}$ & $-0.0305^{* * *}$ & $0.0109^{* *}$ & $-0.4753^{* * *}$ & $0.1276^{*}$ \\
\hline & {$[0.0029]$} & {$[0.0008]$} & {$[0.0056]$} & [0.0009] & {$[0.0055]$} & [0.0037] & {$[0.1667]$} & {$[0.0520]$} \\
\hline High School & $0.0146^{* * * *}$ & $-0.00300^{* * *}$ & 0.004 & $0.0048^{* * *}$ & $-0.0382^{* * *}$ & $0.0089^{* *}$ & $-0.8527^{* * * *}$ & $0.1684^{*}$ \\
\hline & {$[0.0025]$} & {$[0.0008]$} & {$[0.0052]$} & {$[0.0012]$} & {$[0.0057]$} & {$[0.0031]$} & {$[0.1582]$} & {$[0.0678]$} \\
\hline LT High School & $0.0406^{* * *}$ & $-0.0085^{* * *}$ & -0.009 & $0.0053^{* *}$ & $-0.0319^{* * *}$ & 0.0021 & $-0.5450^{* * *}$ & 0.1795 \\
\hline & {$[0.0053]$} & {$[0.0014]$} & {$[0.0069]$} & {$[0.0018]$} & {$[0.0087]$} & {$[0.0027]$} & {$[0.1423]$} & {$[0.0974]$} \\
\hline
\end{tabular}




\begin{tabular}{|c|c|c|c|c|c|c|c|c|}
\hline & \multicolumn{2}{|c|}{ Share of time spent unemployed } & \multicolumn{2}{|c|}{$\begin{array}{l}\text { Share of time spent in the labor } \\
\text { force }\end{array}$} & \multicolumn{2}{|c|}{$\begin{array}{l}\text { Log real } \\
\text { hourly pay }\end{array}$} & \multicolumn{2}{|c|}{$\begin{array}{l}\text { Weekly } \\
\text { hours }\end{array}$} \\
\hline & $\begin{array}{c}\begin{array}{r}\text { Marginal } \\
\text { effect of } \\
\text { high unempl. }\end{array} \\
\text { dUshare } \\
\end{array}$ & $\begin{array}{l}\text { Marginal effect } \\
\text { of HP exposure } \\
\text { oUshare }\end{array}$ & 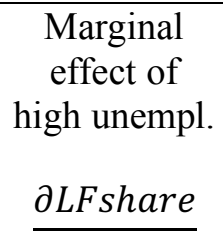 & $\begin{array}{l}\text { Marginal effect } \\
\text { of HP exposure } \\
\partial L F \text { share }\end{array}$ & 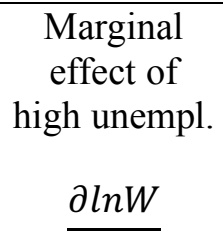 & $\begin{array}{l}\text { Marginal effect } \\
\text { of HP exposure } \\
\partial \ln W \\
\end{array}$ & $\begin{array}{c}\text { Marginal } \\
\text { effect of } \\
\text { high unempl. } \\
\qquad \underline{\partial r S}\end{array}$ & $\begin{array}{l}\text { Marginal } \\
\text { effect of HP } \\
\text { exposure } \\
\text { zHrs }\end{array}$ \\
\hline & $\partial H U$ & $\left.\overline{\partial H P s u m}\right|_{H U=1}$ & $\partial H U$ & $\left.\overline{\partial H P s u m}\right|_{H U=1}$ & $\overline{\partial H U}$ & $\left.\overline{\partial H P s u m}\right|_{H U=1}$ & $\overline{\partial H U}$ & $\left.\overline{\partial H P s u m}\right|_{H U=1}$ \\
\hline Females & $0.0129^{* * *}$ & $-0.0030^{* * *}$ & -0.0022 & $0.0042^{* * *}$ & $-0.0139^{* * *}$ & 0.0044 & -0.2249 & $0.1025^{*}$ \\
\hline & {$[0.0029]$} & {$[0.0006]$} & {$[0.0047]$} & {$[0.0010]$} & {$[0.0040]$} & {$[0.0026]$} & {$[0.1190]$} & {$[0.0420]$} \\
\hline Males & $0.0125^{* * * *}$ & $-0.0018^{* *}$ & 0 & $0.0053^{* * *}$ & $-0.0349^{* * *}$ & $0.0093^{* *}$ & $-0.5338^{* *}$ & 0.1311 \\
\hline & {$[0.0028]$} & {$[0.0007]$} & {$[0.0057]$} & {$[0.0016]$} & {$[0.0039]$} & {$[0.0028]$} & {$[0.1645]$} & {$[0.0715]$} \\
\hline Observations & 253,186 & & 272,186 & & 146,556 & & 155,015 & \\
\hline
\end{tabular}

Notes: Data source is the National Longitudinal Survey of Youth (1979 and 1997). Robust standard errors, in brackets, are clustered at the state level; ***

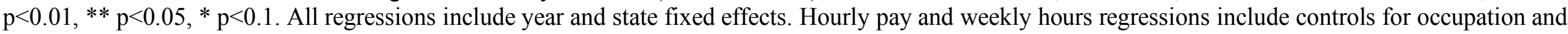

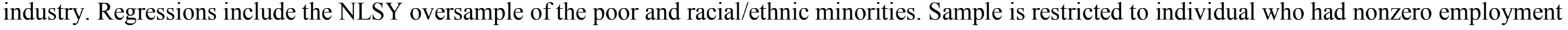
during expansionary periods, positive wage (for log real hourly pay analysis), and positive hours (for weekly hours analysis). Statistically significant moderation of the impact of high unemployment periods from high-pressure exposure are indicated in bold. 
Table C4. Marginal effect of the impact of high-unemployment periods and total high-pressure exposure on log real hourly pay and week hours, by demographic groups, excluding controls for industry and occupation.

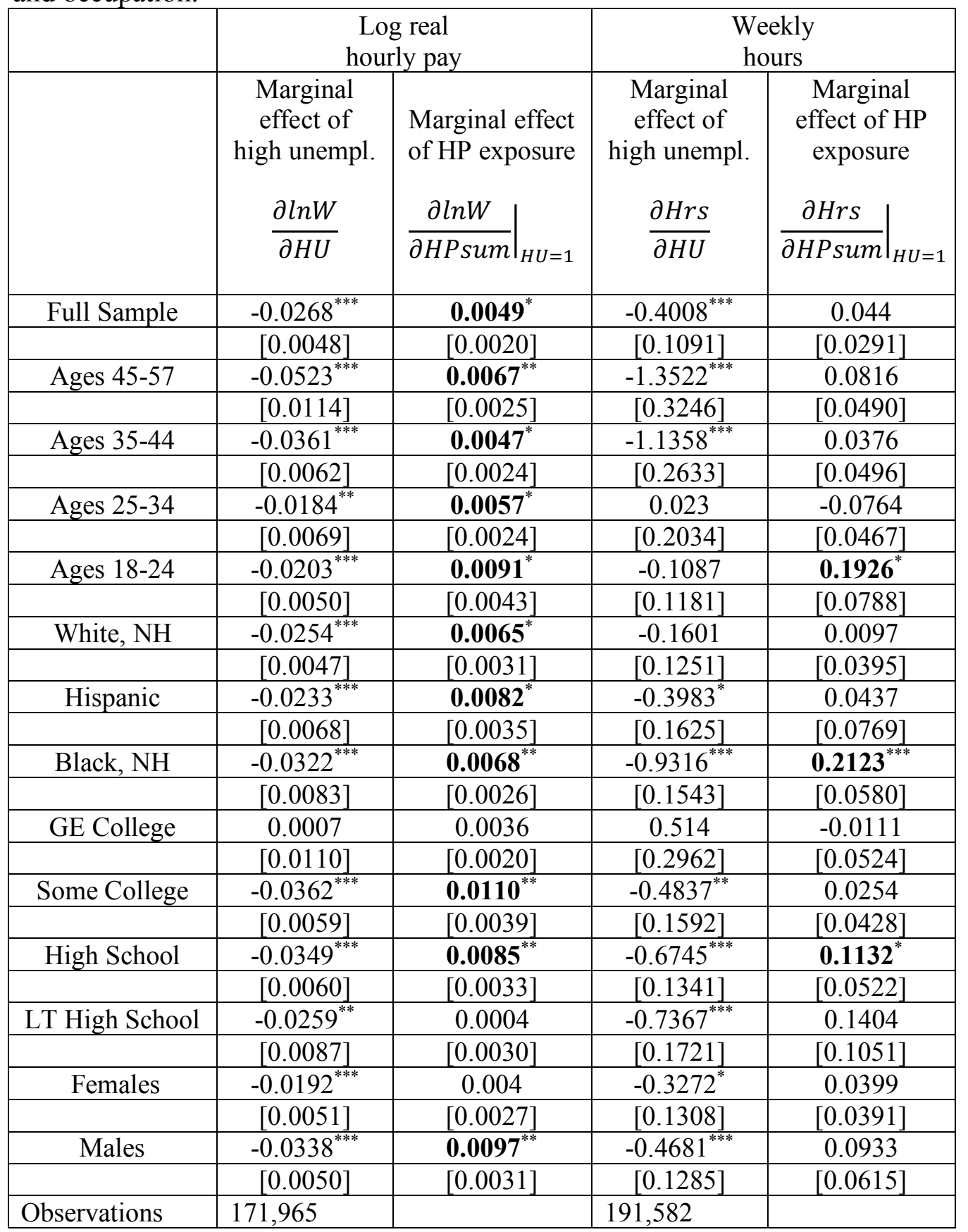

Notes: Data source is the National Longitudinal Survey of Youth (1979 and 1997). Robust standard errors, in brackets, are clustered at the state level; ${ }^{* * *} \mathrm{p}<0.01,{ }^{* *} \mathrm{p}<0.05,{ }^{*} \mathrm{p}<0.1$. All regressions include year, state, and individual fixed effects. Hourly pay and weekly hours regressions include controls for occupation and industry. Regressions include the NLSY oversample of the poor and racial/ethnic minorities. Sample is restricted to individual who had nonzero employment during expansionary periods, positive wage (for log real hourly pay analysis), and positive hours (for weekly hours analysis). Statistically significant moderation of the impact of high unemployment periods from high-pressure exposure are indicated in bold. 
Table C5. Differential marginal effect of the impact of total high-pressure exposure on share of time spent unemployed and share of time spent in the labor force, during high-unemployment periods, based on whether the person moved states between expansion and high-unemployment periods, by demographic group.

\begin{tabular}{|c|c|c|c|c|c|c|c|c|}
\hline & \multicolumn{4}{|c|}{ Share of Time Spent Unemployed } & \multicolumn{4}{|c|}{ Share of Time Spent in the Labor Force } \\
\hline & \multicolumn{2}{|c|}{$\begin{array}{l}\text { Marginal effect of high- } \\
\text { unemployment period }\end{array}$} & \multicolumn{2}{|c|}{$\begin{array}{l}\text { Marginal effect of HP } \\
\text { total exposure }\end{array}$} & \multicolumn{2}{|c|}{$\begin{array}{l}\text { Marginal effect of high- } \\
\text { unemployment period }\end{array}$} & \multicolumn{2}{|c|}{$\begin{array}{l}\text { Marginal effect of HP } \\
\text { total exposure }\end{array}$} \\
\hline & $\begin{array}{l}\text { Same } \\
\text { State }\end{array}$ & $\begin{array}{c}\text { Different } \\
\text { State }\end{array}$ & $\begin{array}{l}\text { Same } \\
\text { State }\end{array}$ & $\begin{array}{l}\text { Different } \\
\text { State }\end{array}$ & $\begin{array}{l}\text { Same } \\
\text { State }\end{array}$ & $\begin{array}{c}\text { Different } \\
\text { State }\end{array}$ & $\begin{array}{l}\text { Same } \\
\text { State }\end{array}$ & $\begin{array}{l}\text { Different } \\
\text { State }\end{array}$ \\
\hline \multirow[t]{2}{*}{ Full Sample } & $0.0120^{* * *}$ & $0.0140^{* * *}$ & $-0.0015^{* * *}$ & 0.0001 & -0.0001 & -0.0042 & $0.0029^{* * *}$ & 0 \\
\hline & {$[0.0025]$} & {$[0.0024]$} & {$[0.0004]$} & {$[0.0008]$} & {$[0.0046]$} & {$[0.0051]$} & {$[0.0008]$} & {$[0.0009]$} \\
\hline \multirow[t]{2}{*}{ Ages 45-57 } & $-0.0192^{*}$ & -0.0129 & -0.0015 & 0.0047 & -0.0027 & -0.014 & 0.0011 & $-0.0102^{*}$ \\
\hline & {$[0.0085]$} & {$[0.0098]$} & {$[0.0012]$} & {$[0.0033]$} & {$[0.0084]$} & {$[0.0101]$} & {$[0.0013]$} & {$[0.0041]$} \\
\hline \multirow[t]{2}{*}{ Ages $35-44$} & 0.0028 & 0.0043 & $-0.0013^{*}$ & 0.0002 & 0.0049 & 0.0009 & -0.0005 & $-0.0047^{* *}$ \\
\hline & {$[0.0045]$} & {$[0.0049]$} & {$[0.0005]$} & {$[0.0011]$} & {$[0.0063]$} & {$[0.0071]$} & {$[0.0011]$} & {$[0.0015]$} \\
\hline \multirow[t]{2}{*}{ Ages 25-34 } & $0.0138^{* * *}$ & $0.0146^{* * *}$ & -0.0002 & 0.0007 & 0.0092 & 0.0063 & 0.0002 & $-0.0029^{*}$ \\
\hline & {$[0.0026]$} & {$[0.0027]$} & {$[0.0007]$} & {$[0.0011]$} & {$[0.0048]$} & {$[0.0053]$} & {$[0.0010]$} & {$[0.0014]$} \\
\hline \multirow[t]{2}{*}{ Ages 18-24 } & $0.0191^{* * *}$ & $0.0218^{* * *}$ & $-0.0048^{* * *}$ & -0.0021 & -0.0062 & -0.009 & $0.0101^{* * *}$ & $0.0072^{* *}$ \\
\hline & {$[0.0038]$} & {$[0.0033]$} & {$[0.0014]$} & {$[0.0017]$} & {$[0.0058]$} & {$[0.0067]$} & {$[0.0029]$} & {$[0.0024]$} \\
\hline \multirow[t]{2}{*}{ White, $\mathrm{NH}$} & $0.0072^{*}$ & $0.0085^{* *}$ & 0.0005 & 0.0019 & 0.0047 & 0.0025 & 0.0013 & -0.0007 \\
\hline & {$[0.0029]$} & {$[0.0028]$} & {$[0.0006]$} & {$[0.0010]$} & {$[0.0045]$} & [0.0047] & {$[0.0010]$} & {$[0.0014]$} \\
\hline \multirow[t]{2}{*}{ Hispanic } & -0.0004 & 0.0004 & -0.0015 & -0.0005 & 0.0054 & 0.0016 & $0.0045^{*}$ & 0.0009 \\
\hline & {$[0.0027]$} & {$[0.0034]$} & {$[0.0010]$} & {$[0.0022]$} & {$[0.0066]$} & {$[0.0090]$} & {$[0.0018]$} & {$[0.0026]$} \\
\hline \multirow[t]{2}{*}{ Black, NH } & $0.0309^{* * *}$ & $0.0354^{* * *}$ & $-0.0085^{* * *}$ & -0.0039 & $-0.0140^{* * *}$ & $-0.0223^{* * *}$ & $0.0092^{* * *}$ & 0.0011 \\
\hline & {$[0.0044]$} & {$[0.0040]$} & {$[0.0014]$} & {$[0.0026]$} & {$[0.0054]$} & {$[0.0067]$} & {$[0.0018]$} & {$[0.0023]$} \\
\hline \multirow[t]{2}{*}{ GE College } & $-0.0078^{* *}$ & $-0.0065^{*}$ & 0.0001 & 0.0015 & 0.0036 & 0.0038 & $0.0041^{*}$ & $0.0046^{* *}$ \\
\hline & {$[0.0029]$} & {$[0.0031]$} & {$[0.0005]$} & {$[0.0011]$} & {$[0.0065]$} & {$[0.0066]$} & {$[0.0021]$} & {$[0.0016]$} \\
\hline \multirow[t]{2}{*}{ Some Coll } & 0.0045 & $0.0065^{*}$ & 0.0006 & 0.0027 & -0.005 & -0.0089 & $0.0034^{* * *}$ & 0 \\
\hline & {$[0.0031]$} & {$[0.0032]$} & {$[0.0007]$} & {$[0.0018]$} & {$[0.0050]$} & {$[0.0062]$} & {$[0.0008]$} & {$[0.0027]$} \\
\hline \multirow[t]{2}{*}{ High Schl } & $0.0134^{* * * *}$ & $0.0144^{* * *}$ & $-0.0025^{* *}$ & -0.0014 & 0.0062 & -0.0014 & $0.0040^{* *}$ & -0.0031 \\
\hline & {$[0.0026]$} & {$[0.0030]$} & {$[0.0008]$} & {$[0.0018]$} & {$[0.0051]$} & {$[0.0061]$} & {$[0.0012]$} & {$[0.0023]$} \\
\hline \multirow[t]{2}{*}{ LT HS } & $0.0390^{* * *}$ & $0.0442^{* * *}$ & $-0.0082^{* * *}$ & -0.0029 & -0.0082 & -0.0113 & $0.0045^{*}$ & 0.0017 \\
\hline & {$[0.0051]$} & {$[0.0049]$} & {$[0.0014]$} & {$[0.0030]$} & {$[0.0067]$} & {$[0.0082]$} & {$[0.0019]$} & {$[0.0031]$} \\
\hline \multirow[t]{2}{*}{ Females } & $0.0123^{* * *}$ & $0.0161^{* * *}$ & $-0.0030^{* * *}$ & 0.0009 & -0.0012 & $-0.0111^{*}$ & $0.0042^{* * *}$ & $-0.0055^{* *}$ \\
\hline & {$[0.0029]$} & {$[0.0027]$} & {$[0.0007]$} & {$[0.0015]$} & {$[0.0045]$} & {$[0.0054]$} & {$[0.0012]$} & {$[0.0018]$} \\
\hline \multirow[t]{2}{*}{ Males } & $0.0117^{* * * *}$ & $0.0120^{* * * *}$ & $-0.0015^{*}$ & -0.0009 & 0.001 & 0.0027 & $0.0038^{* *}$ & $0.0055^{* * * *}$ \\
\hline & {$[0.0028]$} & {$[0.0029]$} & {$[0.0007]$} & {$[0.0010]$} & {$[0.0055]$} & {$[0.0059]$} & {$[0.0014]$} & {$[0.0015]$} \\
\hline Obs $=$ & \multicolumn{4}{|c|}{253,186} & \multicolumn{4}{|c|}{272,186} \\
\hline
\end{tabular}

Notes: Data source is the National Longitudinal Survey of Youth (1979 and 1997). Robust standard errors, in brackets, are clustered at the state level; $* * * \mathrm{p}<0.01, * * \mathrm{p}<0.05, * \mathrm{p}<0.1$. Regression includes year, state, and individual fixed effects.

Regressions include the NLSY oversample of the poor and racial/ethnic minorities. Sample is restricted to individual who had nonzero employment during expansionary periods. Sample is restricted to individual who had nonzero employment during expansionary periods. Statistically significant moderation of the impact of high unemployment periods from high-pressure exposure are indicated in bold. 
Table C6. Differential marginal effect of the impact of total high-pressure exposure on log real hourly pay and weekly hours of work, during high-unemployment periods, based on whether the person moved states between expansion and high-unemployment periods, by demographic group.

\begin{tabular}{|c|c|c|c|c|c|c|c|c|}
\hline & \multicolumn{4}{|c|}{ Log Real Hourly Pay } & \multicolumn{4}{|c|}{ Weekly Hours } \\
\hline & \multicolumn{2}{|c|}{$\begin{array}{l}\text { Marginal effect of high- } \\
\text { unemployment period }\end{array}$} & \multicolumn{2}{|c|}{$\begin{array}{c}\text { Marginal effect of HP } \\
\text { total exposure }\end{array}$} & \multicolumn{2}{|c|}{$\begin{array}{l}\text { Marginal effect of high- } \\
\text { unemployment period }\end{array}$} & \multicolumn{2}{|c|}{$\begin{array}{c}\text { Marginal effect of HP } \\
\text { total exposure }\end{array}$} \\
\hline & $\begin{array}{l}\text { Same } \\
\text { State }\end{array}$ & $\begin{array}{l}\text { Different } \\
\text { State }\end{array}$ & $\begin{array}{l}\text { Same } \\
\text { State }\end{array}$ & $\begin{array}{l}\text { Different } \\
\text { State }\end{array}$ & $\begin{array}{l}\text { Same } \\
\text { State }\end{array}$ & $\begin{array}{l}\text { Different } \\
\text { State }\end{array}$ & $\begin{array}{l}\text { Same } \\
\text { State }\end{array}$ & $\begin{array}{l}\text { Different } \\
\text { State } \\
\end{array}$ \\
\hline \multirow[t]{2}{*}{ Full Sample } & $-0.0220^{* * *}$ & $-0.0341^{* * *}$ & $0.0034^{*}$ & 0.0028 & $-0.2873^{* *}$ & $-0.5366^{*}$ & 0.0165 & -0.0155 \\
\hline & {$[0.0036]$} & {$[0.0103]$} & {$[0.0015]$} & {$[0.0040]$} & {$[0.1087]$} & {$[0.2622]$} & {$[0.0243]$} & {$[0.1333]$} \\
\hline \multirow[t]{2}{*}{ Ages 45-57 } & $-0.0427^{* * *}$ & $-0.0377^{*}$ & $0.0057^{* *}$ & 0.0104 & $-0.9141^{*}$ & -0.1799 & 0.05 & 0.6959 \\
\hline & {$[0.0109]$} & {$[0.0173]$} & {$[0.0018]$} & {$[0.0126]$} & {$[0.3781]$} & {$[0.8131]$} & {$[0.0396]$} & {$[0.5925]$} \\
\hline \multirow[t]{2}{*}{ Ages 35-44 } & $-0.0237^{* * *}$ & $-0.0947^{* *}$ & 0.0034 & $-0.0606^{*}$ & $-0.7004^{* * *}$ & $-2.1670^{* * *}$ & 0.0119 & $-1.3362^{*}$ \\
\hline & {$[0.0044]$} & {$[0.0338]$} & {$[0.0018]$} & {$[0.0300]$} & {$[0.1988]$} & {$[0.6061]$} & [0.0344] & {$[0.5601]$} \\
\hline \multirow[t]{2}{*}{ Ages 25-34 } & -0.0141 & -0.0141 & $0.0051^{*}$ & 0.0054 & 0.0679 & 0.0585 & -0.0703 & -0.0982 \\
\hline & {$[0.0077]$} & {$[0.0098]$} & {$[0.0024]$} & {$[0.0062]$} & {$[0.2148]$} & {$[0.2749]$} & {$[0.0447]$} & {$[0.1730]$} \\
\hline \multirow[t]{2}{*}{ Ages 18-24 } & $-0.0201^{* * *}$ & 0.0022 & 0.0049 & $0.0253^{* * *}$ & -0.1046 & -0.0202 & 0.1253 & 0.1825 \\
\hline & {$[0.0049]$} & {$[0.0102]$} & {$[0.0032]$} & {$[0.0067]$} & {$[0.0923]$} & {$[0.2549]$} & {$[0.0703]$} & {$[0.2289]$} \\
\hline \multirow[t]{2}{*}{ White, NH } & $-0.0197^{* * *}$ & $-0.0342^{* * *}$ & 0.0043 & -0.0014 & -0.097 & -0.1754 & -0.0244 & -0.0193 \\
\hline & {$[0.0042]$} & {$[0.0090]$} & {$[0.0022]$} & {$[0.0061]$} & {$[0.1247]$} & {$[0.3516]$} & {$[0.0338]$} & {$[0.2780]$} \\
\hline \multirow[t]{2}{*}{ Hispanic } & $-0.0117^{*}$ & -0.0237 & 0.0033 & 0 & $-0.3359^{*}$ & -0.3429 & 0.0384 & 0.1083 \\
\hline & {$[0.0052]$} & {$[0.0151]$} & {$[0.0031]$} & {$[0.0104]$} & {$[0.1585]$} & {$[0.5047]$} & {$[0.0755]$} & {$[0.3848]$} \\
\hline \multirow[t]{2}{*}{ Black, NH } & $-0.0347^{* * *}$ & $-0.0419^{*}$ & $0.0070^{* *}$ & 0.0079 & $-0.6505^{* * *}$ & $-1.4303^{* *}$ & $0.1511^{* *}$ & -0.4792 \\
\hline & {$[0.0068]$} & {$[0.0167]$} & {$[0.0022]$} & {$[0.0121]$} & {$[0.1381]$} & {$[0.4555]$} & {$[0.0520]$} & {$[0.3559]$} \\
\hline \multirow[t]{2}{*}{ GE College } & 0.0177 & 0.0067 & -0.0005 & -0.0032 & $0.7393^{* *}$ & $1.1244^{* *}$ & $-0.0806^{*}$ & 0.3684 \\
\hline & {$[0.0101]$} & {$[0.0158]$} & {$[0.0013]$} & {$[0.0102]$} & {$[0.2465]$} & {$[0.3882]$} & {$[0.0371]$} & {$[0.2684]$} \\
\hline \multirow[t]{2}{*}{ Some Coll } & $-0.0271^{* * *}$ & $-0.0322^{* *}$ & $0.0084^{* * *}$ & 0.011 & $-0.3421^{*}$ & $-0.7233^{*}$ & 0.0153 & -0.2299 \\
\hline & {$[0.0058]$} & {$[0.0125]$} & {$[0.0032]$} & {$[0.0085]$} & {$[0.1587]$} & {$[0.2826]$} & {$[0.0347]$} & {$[0.2033]$} \\
\hline \multirow[t]{2}{*}{ High Schl } & $-0.0376^{* * *}$ & $-0.0685^{* * *}$ & $0.0069^{*}$ & -0.0138 & $-0.7792^{* * *}$ & $-1.6337^{* * *}$ & 0.0901 & -0.584 \\
\hline & {$[0.0056]$} & {$[0.0148]$} & {$[0.0028]$} & {$[0.0104]$} & {$[0.1537]$} & {$[0.4393]$} & {$[0.0530]$} & {$[0.3455]$} \\
\hline \multirow[t]{2}{*}{ LT HS } & $-0.0293^{* * *}$ & -0.0144 & 0 & 0.0207 & $-0.4467^{* * *}$ & -0.1475 & 0.0975 & 0.4687 \\
\hline & {$[0.0084]$} & {$[0.0167]$} & {$[0.0025]$} & {$[0.0145]$} & {$[0.1322]$} & {$[0.4297]$} & {$[0.1018]$} & {$[0.3698]$} \\
\hline \multirow[t]{2}{*}{ Females } & $-0.0137^{* *}$ & $-0.0347^{*}$ & 0.0027 & -0.0088 & -0.2216 & -0.4507 & 0.0229 & -0.106 \\
\hline & {$[0.0043]$} & {$[0.0136]$} & {$[0.0023]$} & {$[0.0108]$} & {$[0.1286]$} & {$[0.3586]$} & {$[0.0361]$} & {$[0.2789]$} \\
\hline \multirow[t]{2}{*}{ Males } & $-0.0299^{* * *}$ & $-0.0335^{* *}$ & $0.0068^{* *}$ & 0.0109 & $-0.3486^{* * *}$ & $-0.6170^{*}$ & 0.0431 & -0.1214 \\
\hline & {$[0.0037]$} & {$[0.0114]$} & {$[0.0023]$} & {$[0.0079]$} & {$[0.1342]$} & {$[0.2689]$} & {$[0.0580]$} & {$[0.2188]$} \\
\hline $\mathrm{Obs}=$ & \multicolumn{4}{|c|}{146,566} & \multicolumn{4}{|c|}{155,015} \\
\hline
\end{tabular}

Notes: Data source is the National Longitudinal Survey of Youth (1979 and 1997). Robust standard errors, in brackets, are clustered at the state level; $* * * \mathrm{p}<0.01,{ }^{*} \mathrm{p}<0.05,{ }^{*} \mathrm{p}<0.1$. Regression includes year, state, and individual fixed effects.

Regressions include the NLSY oversample of the poor and racial/ethnic minorities. Sample is restricted to individual who had nonzero employment during expansionary periods. Analysis restricts sample to those with positive earnings and positive hours of work, respectively. Statistically significant moderation of the impact of high unemployment periods from high-pressure exposure are indicated in bold. 